\title{
Article
}

\section{Time-Lapse Flow Cytometry: A Robust Tool to Assess Physiological Parameters Related to the Fertilizing Capability of Human Sperm}

\author{
Arturo Matamoros-Volante ${ }^{1,+}{ }^{\circledR}$, Valeria Castillo-Viveros ${ }^{1,+}{ }^{,}$, Paulina Torres-Rodríguez ${ }^{1}$, Marcela B. Treviño ${ }^{2}$ and \\ Claudia L. Treviño ${ }^{1, *}$ \\ 1 Departamento de Genética del Desarrollo y Fisiología Molecular, Instituto de Biotecnología, \\ Universidad Nacional Autónoma de México, Cuernavaca Morelos 62210, Mexico; \\ arturo.matamoros@mail.ibt.unam.mx (A.M.-V.); linda.castillo@mail.ibt.unam.mx (V.C.-V.); \\ torresp@ibt.unam.mx (P.T.-R.) \\ 2 Science Department, School of Pure and Applied Sciences, Florida SouthWestern State College, \\ Fort Myers, FL 33919, USA; marcela.trevino@fsw.edu \\ * Correspondence: claudia.trevino@mail.ibt.unam.mx; Tel.: +52-777-329-1611 \\ + These authors contributed equally.
}

Citation: Matamoros-Volante, A.; Castillo-Viveros, V.; Torres-Rodríguez, P.; Treviño, M.B.; Treviño, C.L. TimeLapse Flow Cytometry: A Robust Tool to Assess Physiological Parameters Related to the Fertilizing Capability of Human Sperm. Int. J. Mol. Sci. 2021, 22, 93. https://dx.doi.org/10.3390/ ijms22010093

Received: 27 November 2020 Accepted: 16 December 2020

Published: 24 December 2020

Publisher's Note: MDPI stays neutral with regard to jurisdictional claims in published maps and institutional affiliations.

Copyright: (c) 2020 by the authors. Licensee MDPI, Basel, Switzerland. This article is an open access article distributed under the terms and conditions of the Creative Commons Attribution (CC BY) license (https: / / creativecommons.org/ licenses/by/4.0/).

\begin{abstract}
Plasma membrane (PM) hyperpolarization, increased intracellular $\mathrm{pH}\left(\mathrm{pH}_{\mathrm{i}}\right)$, and changes in intracellular calcium concentration $\left(\left[\mathrm{Ca}^{2+}\right]_{\mathrm{i}}\right)$ are physiological events that occur during human sperm capacitation. These parameters are potential predictors of successful outcomes for men undergoing artificial reproduction techniques (ARTs), but methods currently available for their determination pose various technical challenges and limitations. Here, we developed a novel strategy employing time-lapse flow cytometry (TLFC) to determine capacitation-related membrane potential $\left(E_{\mathrm{m}}\right)$ and $\mathrm{pH}_{\mathrm{i}}$ changes, and progesterone-induced $\left[\mathrm{Ca}^{2+}\right]_{\mathrm{i}}$ increases. Our results show that TLFC is a robust method to measure absolute $E_{\mathrm{m}}$ and $\mathrm{pH}_{\mathrm{i}}$ values and to qualitatively evaluate $\left[\mathrm{Ca}^{2+}\right]_{\mathrm{i}}$ changes To support the usefulness of our methodology, we used sperm from two types of normozoospermic donors: known paternity (subjects with self-reported paternity) and no-known paternity (subjects without self-reported paternity and no known fertility problems). We found relevant differences between them. The incidences of membrane hyperpolarization, $\mathrm{pH}_{\mathrm{i}}$ alkalinization, and increased $\left[\mathrm{Ca}^{2+}\right]_{\mathrm{i}}$ were consistently high among known paternity samples $(100 \%, 100 \%$, and $86 \%$, respectively), while they varied widely among no-known paternity samples (44\%, 17\%, and $45 \%$, respectively). Our results indicate that TLFC is a powerful tool to analyze key physiological parameters of human sperm, which pending clinical validation, could potentially be employed as fertility predictors.
\end{abstract}

Keywords: time-lapse flow cytometry; membrane potential; intracellular calcium; intracellular pH; sperm capacitation; sperm fertilizing capability

\section{Introduction}

Sexual reproduction involves the successful fusion of the female (egg or oocyte) and male (sperm) gametes, a process called fertilization. Human fertility-related issues are a growing public health problem worldwide [1]. The causes of human infertility are multifactorial and the prevalence among females and males occurs in the same proportion [2,3]. Regarding male factors, sperm dysfunctions are considered to be the most frequent etiology of fertility issues [4]. The most common approach to detect such dysfunctions on sperm is through the evaluation of macro- and microscopic seminal parameters (i.e., semen volume and $\mathrm{pH}$, sperm motility, vitality, and morphology), which are collectively known as the seminogram [5]. The World Health Organization (WHO) updated the reference values for the seminogram analysis in 2010 [6]. Men who fulfill these reference values are considered normozoospermic and are therefore presumed to be fertile. However, the usefulness of these parameters as predictors of reproductive outcomes has been on debate for seven 
decades, given that the reference values observed in fertile men usually overlap with those obtained in men with fertility issues [6-8]. Thus, the sole evaluation of seminogram parameters is not sufficient to unequivocally establish whether a male individual is fertile or infertile $[9,10]$.

As a result, various efforts have been made to correlate the fertilizing capability of sperm with some of the physiological events that take place during sperm capacitation, a multistep phenomenon involving changes in sperm form and function [11], which is essential for fertilization, and which encompasses various molecular processes that sperm cells undergo during their transit inside the female reproductive tract [12-14]. Among these processes we can distinguish (a) changes in the plasma membrane's ion permeability, which result in its hyperpolarization ([15-17], reviewed in [18]); (b) an increase in intracellular $\mathrm{pH}$ $\left(\mathrm{pH}_{\mathrm{i}}\right)$ [19-21]; and (c) a rise in intracellular calcium concentration $\left(\left[\mathrm{Ca}^{2+}\right]_{\mathrm{i}}\right)$ upon exposure to progesterone $\mathrm{Pg}$, a female hormone secreted by cumulus oophorus cells that surround the oocyte) [22-24]. These parameters have been independently analyzed in sperm samples from men with fertility issues, and results show that after capacitation induction, their sperm cells do not undergo $\mathrm{pH}_{\mathrm{i}}$ alkalinization, and they also fail to hyperpolarize (in some cases they depolarize) their plasma membrane (PM) $[17,25-28]$. Regarding $\left[\mathrm{Ca}^{2+}\right]_{\mathrm{i}}$ changes, some reports suggest that sperm cells from men with fertility issues present a decreased response to $\operatorname{Pg}[29,30]$. Collectively, these shreds of evidence support the notion that the evaluation of sperm capacitation-related parameters may potentially serve as a tool to predict outcomes for different artificial reproduction techniques (ARTs), which may in turn help guide ART selection for men seeking to overcome fertility issues.

The methods currently employed to analyze the aforementioned capacitation-related parameters include single cell-based approaches, such as time-lapse fluorescence videomicroscopy [29] and the electrophysiological patch-clamp technique [25,31,32]. These procedures present the disadvantage of only permitting the analysis of a limited number of cells, which can mask heterogeneous responses and therefore yield inaccurate results. Other methods include population-based approaches, such as spectrofluorometry $[17,26]$ and flow cytometry $[27,28]$, which analyze the behavior of an entire sperm cell sample population. Spectrofluorometry poses the disadvantage of only permitting the recording of average responses, and as a result, some non-homogeneous responses may also be masked. In contrast, flow cytometry evaluates single-cell responses for a large number of cells, thus enabling identification, if present, of cell subpopulations with heterogeneous responses. Furthermore, flow cytometry enables the simultaneous use of several markers to evaluate different cellular parameters. However, conventional flow cytometers are not fitted for the continuous addition of test compounds to the cell suspension since the pressurized system for sample aspiration requires the creation of a vacuum. When using these instruments, it is therefore necessary to pause aspiration in order to proceed with reagent addition. Due to the time delay between each addition, such stopped-flow cytometry methods are not useful for the performance of continuous measurements, which are required for the observation of fast and/or transient responses. The BD Accuri C6 Plus flow cytometers are suitable instruments to overcome these limitations because they operate with a peristaltic pump, eliminating the need for vacuum creation. Continuous compound additions are thus feasible through manual pipetting, enabling the possibility of conducting time-lapse fluorescence recordings for a large cell population, with single-cell resolution [33,34].

Taking advantage of this instrument's unique feature, we developed a novel method, which we have named time-lapse flow cytometry (TLFC). Our main findings suggest that TLFC is suitable for measurements of both membrane potential $\left(E_{\mathrm{m}}\right)$ and $\mathrm{pH}_{\mathrm{i}}$ absolute values, as well as for the qualitative evaluation of $\left[\mathrm{Ca}^{2+}\right]_{i}$ changes. We compared all three cellular responses in sperm cells incubated under conditions that either support or do not support in vitro capacitation. We also found promising preliminary results when comparing the incidence of the three capacitation parameters in sperm samples from normozoospermic donors with self-reported paternity (known paternity) versus donors with no self-reported paternity and no known fertility issues (no-known paternity). Altogether, 
our results lead us to propose TLFC as a robust method for the analysis of physiological parameters in human sperm cells, with the potential for use in male fertility evaluations and ART selection.

\section{Results}

\subsection{Measurement of $E_{m}$ Absolute Values in Human Sperm Using TLFC Recordings}

PM hyperpolarization occurs during sperm capacitation [15,35,36], and this physiological event has been suggested as a predictor of success output during ART implementation $[26,27]$. For this reason, we established a strategy to evaluate the $E_{\mathrm{m}}$ of human sperm employing TLFC using 3,3'dipropylthiadicarbocyanine iodide $\left(\operatorname{DiSC}_{3}(5)\right.$, abbreviated to Disc), a cationic carbocyanine $E_{\mathrm{m}}$-sensitive probe. This fluorescent dye partitions into the sperm PM according to its $E_{\mathrm{m}}$-when the PM becomes hyperpolarized, Disc will accumulate in the PM due to its cationic nature, while a depolarization favors the dye's efflux from the cell, resulting in decreased fluorescence [37]. Taking advantage of the multiparameter analysis that flow cytometry permits, we loaded sperm samples with 4-(6-acetoxymethoxy-2,7dichloro-3-oxo-9-xanthenyl)-4' -methyl-2,2' (ethylenedioxy) dianiline- $\mathrm{N}, \mathrm{N}, \mathrm{N}^{\prime}, \mathrm{N}^{\prime}$-tetra acetic acid tetrakis (acetoxymethyl) ester (Fluo3-AM, abbreviated to Fluo3) prior to the experiment. This $\mathrm{Ca}^{2+}$-sensitive probe exhibits an increase in fluorescence upon binding $\mathrm{Ca}^{2+}$, indirectly allowing the exclusion of non-viable cells from the analysis (see Section 4.5 and Figure S1 for details). After co-staining each sperm sample with Disc, we performed fluorescence recordings in an BD Accuri C6 Plus flow cytometer retrofitted with our custom-built system for the continuous addition of reagents (see Section 4.4 and Figure 1).

First, resting-state Disc fluorescence was recorded for $120 \mathrm{~s}$. This was immediately followed by the addition of the $\mathrm{K}^{+}$ionophore valinomycin $(1 \mu \mathrm{M})$, which evoked pharmacological clamping of $E_{\mathrm{m}}$ by transforming the sperm PM into a " $\mathrm{K}^{+}$electrode". This resulted in a net movement of $\mathrm{K}^{+}$ions out of the cell until the $\mathrm{K}^{+}$reversal potential was reached, causing membrane hyperpolarization, which in turn brought about the accumulation of Disc in the lipid bilayer of the PM and the concomitant rise in PM fluorescence. After reaching a fluorescence plateau, sequential additions of $\mathrm{KCl}$ were made to elicit $\mathrm{K}^{+}$influx and therefore trigger membrane depolarization $(\mathrm{KCl}$ was added in the amounts required to reach the $E_{\mathrm{m}}$ target values of $-80,-63,-52,-40$, and $-28 \mathrm{mV}$ ) (Figure $2 \mathrm{a}$ ). Then, the median fluorescence value for the responding sperm subpopulation (indicated in gray boxes in Figure 2a) when the plateau was reached was plotted against the theoretical $E_{\mathrm{m}}$ value obtained by applying the Nernst's equation (Figure $2 b$ ). A linear model was fitted to these data, and fluorescence values were interpolated to calculate the corresponding resting $E_{\mathrm{m}}$ values (Figure $2 b, c)$. In this experiment, which was used as a representative example, the calculated resting $E_{\mathrm{m}}$ value for the sperm subpopulation was $-65 \mathrm{mV}$ (Figure 2c, gray histogram). This resting $E_{\mathrm{m}}$ value is consistent with previously reported data [26,27], strongly suggesting that our TLFC method is suitable for measuring absolute $E_{\mathrm{m}}$ values in the human sperm model. As a proof of concept, we employed this method to evaluate the $E_{\mathrm{m}}$ of sperm samples incubated in either non-capacitating (NC) or capacitating (CAP) conditions. We analyzed samples from two distinct classes of normozoospermic donors: (i) known paternity subjects, who had self-reported paternity $(n=6)$, and (ii) no-known paternity subjects, who had no self-reported paternity and no known fertility issues $(n=9)$. In concordance with previous reports where $E_{\mathrm{m}}$ was measured using flow cytometry [26,27], we found a high level of heterogeneity in resting $E_{\mathrm{m}}$ values across samples, especially among the noknown paternity group. Actually, in samples from this donor class, we observed only a slight and non-statistically significant difference in resting $E_{\mathrm{m}}$ between NC and CAP conditions $(-67 \pm 4$ and $-70 \pm 3 \mathrm{mV}$, respectively; $p=0.25)$. Interestingly, we detected a capacitationinduced hyperpolarization in all known paternity samples $(-60 \pm 3$ versus $-71 \pm 3 \mathrm{mV}$ for $\mathrm{NC}$ and CAP conditions, respectively; $p=0.01$ ) (Figure 2d). To further analyze these data, we calculated the average $E_{\mathrm{m}}$ changes upon capacitation $\left(\Delta E_{\mathrm{m}}=E_{\mathrm{mCAP}}-E_{\mathrm{mNC}}\right)$ (Figure 2e). As previously reported [26], a $\Delta E_{\mathrm{m}}= \pm 5 \mathrm{mV}$ was established as the threshold value to consider a sperm sample as either undergoing PM depolarization $\left(\Delta E_{\mathrm{m}}>5 \mathrm{mV}\right)$ or 
hyperpolarization $\left(\Delta E_{\mathrm{m}}<5 \mathrm{mV}\right)$. Using these criteria, we found that $44 \%$ of the no-known paternity samples were either hyperpolarized or unchanged upon capacitation, while only 1 out of 9 samples (12\%) underwent depolarization. In contrast, $100 \%$ of the known paternity samples displayed the expected capacitation-associated hyperpolarization (Figure 2f).
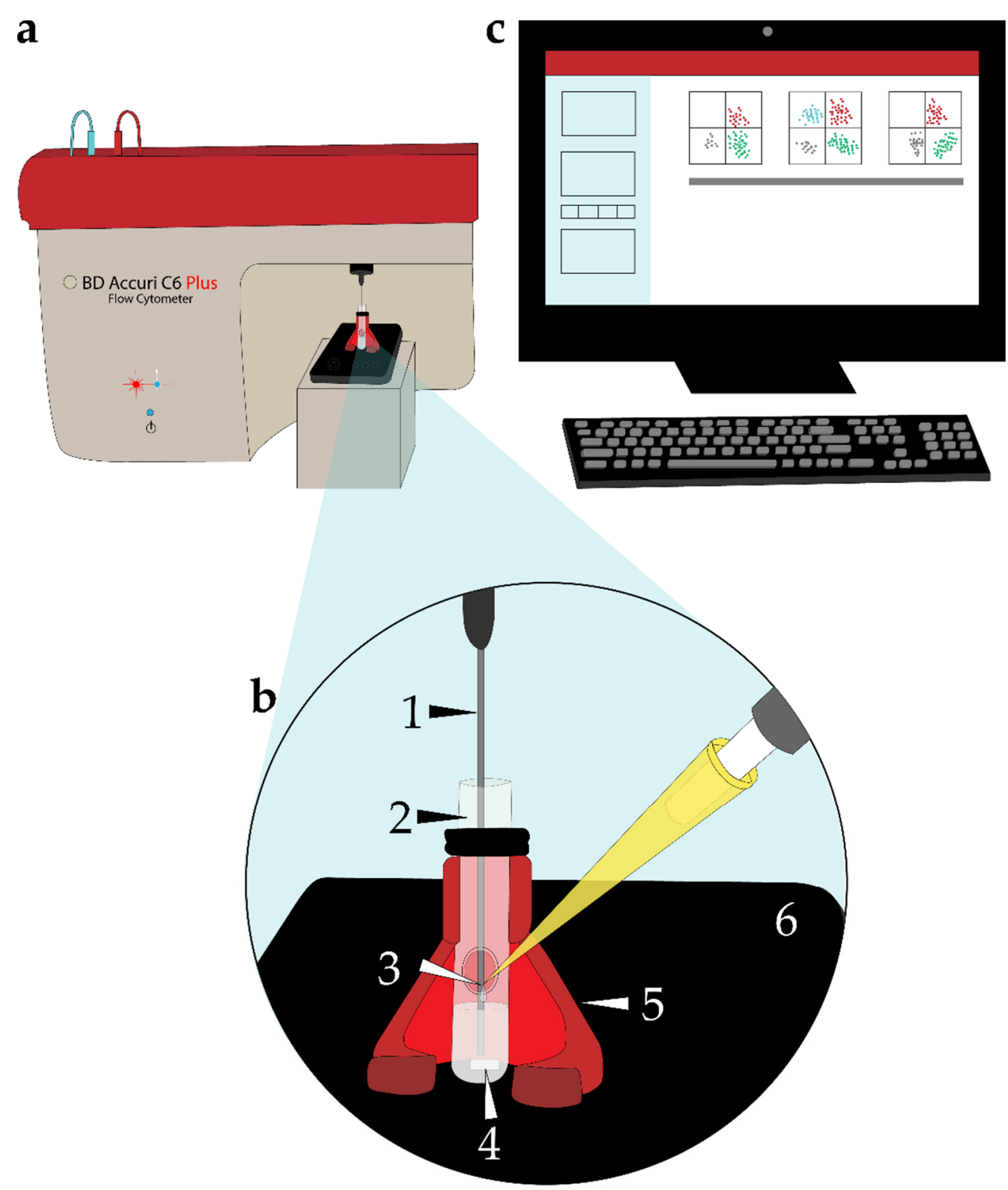

Figure 1. Schematic diagram of the time-lapse flow cytometry (TLFC) instrument setup. (a) BD Accuri C6 Plus flow cytometer retrofitted with a custom-built time-lapse measurement system. (b) Detail of the custom-built component to perform continuous reagent additions and to ensure homogeneous sample mixing during data acquisition. (1) Sample injection port (SIP) consisting of a sample injection tube through which the sample travels to the flow cell to be introduced to the sheath fluid. (2) Modified glass tube with a port (side opening) to enable the continuous addition of reagents to the cell suspension. (3) Reagent addition to the cell suspension was accomplished through micropipetting. (4) Magnetic stir bar. (5) 3D-printed tube holder specifically built to accommodate the modified glass tube. (6) Magnetic stir plate for the continuous mixing of the cell suspension throughout the entire data acquisition period. (c) Desktop computer running the BD Accuri C6 Plus software program. 

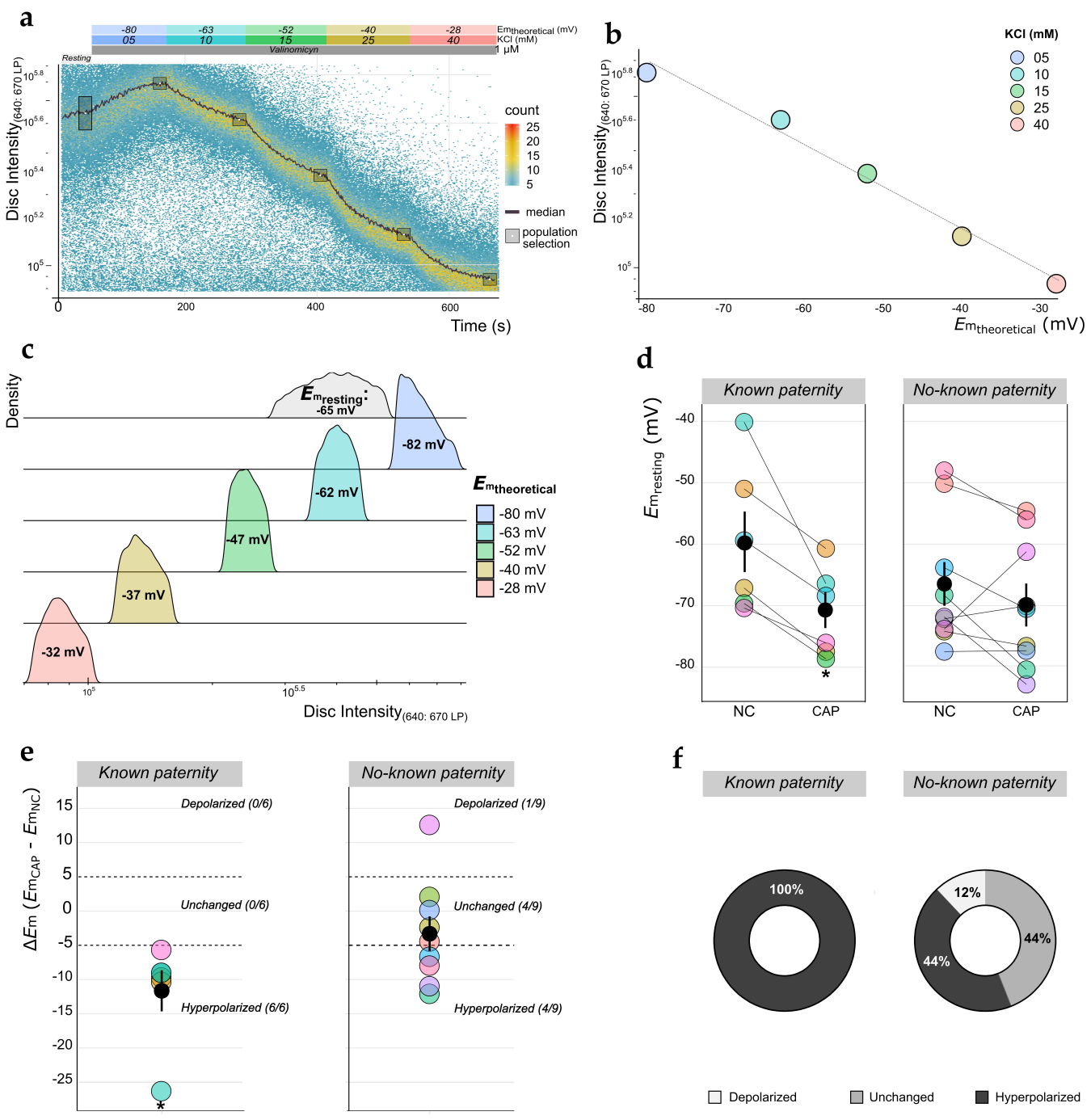

Figure 2. Measurement of membrane potential $\left(E_{\mathrm{m}}\right)$ absolute values in human sperm. (a) Representative time-lapse flow cytometry (TLFC) 3,3' dipropylthiadicarbocyanine iodide ( $\operatorname{DiSC}_{3}(5)$, abbreviated to Disc) fluorescence density plot of a sperm sample from a known paternity donor under capacitating (CAP) conditions. Colored boxes above the plot indicate the nature and duration of the employed stimuli. The dark solid line indicates the median fluorescence value. Gray boxes enclose the cell subpopulations selected for further calculations. (b) Median fluorescence values for the selected cell subpopulations indicated in (a) were plotted against the theoretical $E_{\mathrm{m}}$ value (calculated using Nernst's equation). The dashed line indicates the linear fit $\left(y=-10,682.4 x-264,308 ; R^{2}=0.95 ; p=0.003\right)$. (c) Density histograms of Disc fluorescence values from the subpopulations indicated in (a). For comparison, each colored histogram corresponds to each of the $E_{\mathrm{m}}$ values (indicated inside histograms) estimated using the linear fit in (a); the interpolated resting $E_{\mathrm{m}}$ value (gray histogram) of the resting sperm subpopulation was $-65 \mathrm{mV}$. (d) Plots of calculated $E_{\mathrm{m}}$ values for individual sperm samples (shown color-coded) incubated under either non-capacitating (NC) or CAP conditions, from either known $(n=6)$ or no-known $(n=9)$ paternity donors. Black dots and solid lines indicate mean \pm standard error of the mean (SEM), respectively; ${ }^{*} p<0.05$ against NC according to a paired $t$-test. (e) Plots of capacitation-induced $E_{\mathrm{m}}$ change $\left(\Delta E_{\mathrm{m}}=E_{\mathrm{mCAP}}-E_{\mathrm{mNC}}\right)$ for samples in (d). Samples with a $\Delta E_{\mathrm{m}}$ value greater, lower, or equal to $\pm 5 \mathrm{mV}$ were classified (dotted lines) as depolarized, hyperpolarized, or unchanged, respectively; numbers in parentheses indicate the number of samples in each category out of the total. Black dots and solid lines indicate mean $\pm \mathrm{SEM} ;{ }^{*} p<0.05$ according to a one-sample $t$-test comparison against a theoretical mean of $\Delta E_{\mathrm{m}}=0$. (f) Donut charts depicting the distribution of the results shown in (e). 


\subsection{Simultaneous Measurement of $E_{m}$ and Evaluation of $\left[\mathrm{Ca}^{2+}\right]_{i}$ Changes in Human Sperm Using TLFC Recordings}

As mentioned before, our TLFC measurements of $E_{\mathrm{m}}$ were performed by employing cells stained with two different dyes-Fluo3 and Disc. Such co-staining capability offers an opportunity for the simultaneous evaluation of more than one physiological parameter, up to four, provided that the required fluorescent dyes are compatible. In this case, the combined use of Fluo3 and Disc allowed us to simultaneously analyze changes in $\left[\mathrm{Ca}^{2+}\right]_{\mathrm{i}}$ during the protocol for $E_{\mathrm{m}}$ measurements. Interestingly, in most of the sperm samples tested, Fluo3 fluorescence rapidly dropped after PM hyperpolarization with valinomycin, reaching a minimum after $60 \mathrm{~s}$, followed by a recovery phase (Figure $3 a, b)$. Then, in all sperm samples analyzed, depolarization pulses triggered by sequential $\mathrm{KCl}$ additions evoked a transient $\left[\mathrm{Ca}^{2+}\right]_{\mathrm{i}}$ increase. For comparison purposes, we normalized fluorescence values by setting the basal levels to zero, which was accomplished by subtracting the average of the basal level $\left(\mathrm{F}_{0}\right)$ from each value fluorescence $(\mathrm{F})$ and dividing by $\mathrm{F}_{0}$ (Figure $3 \mathrm{c}$ ).
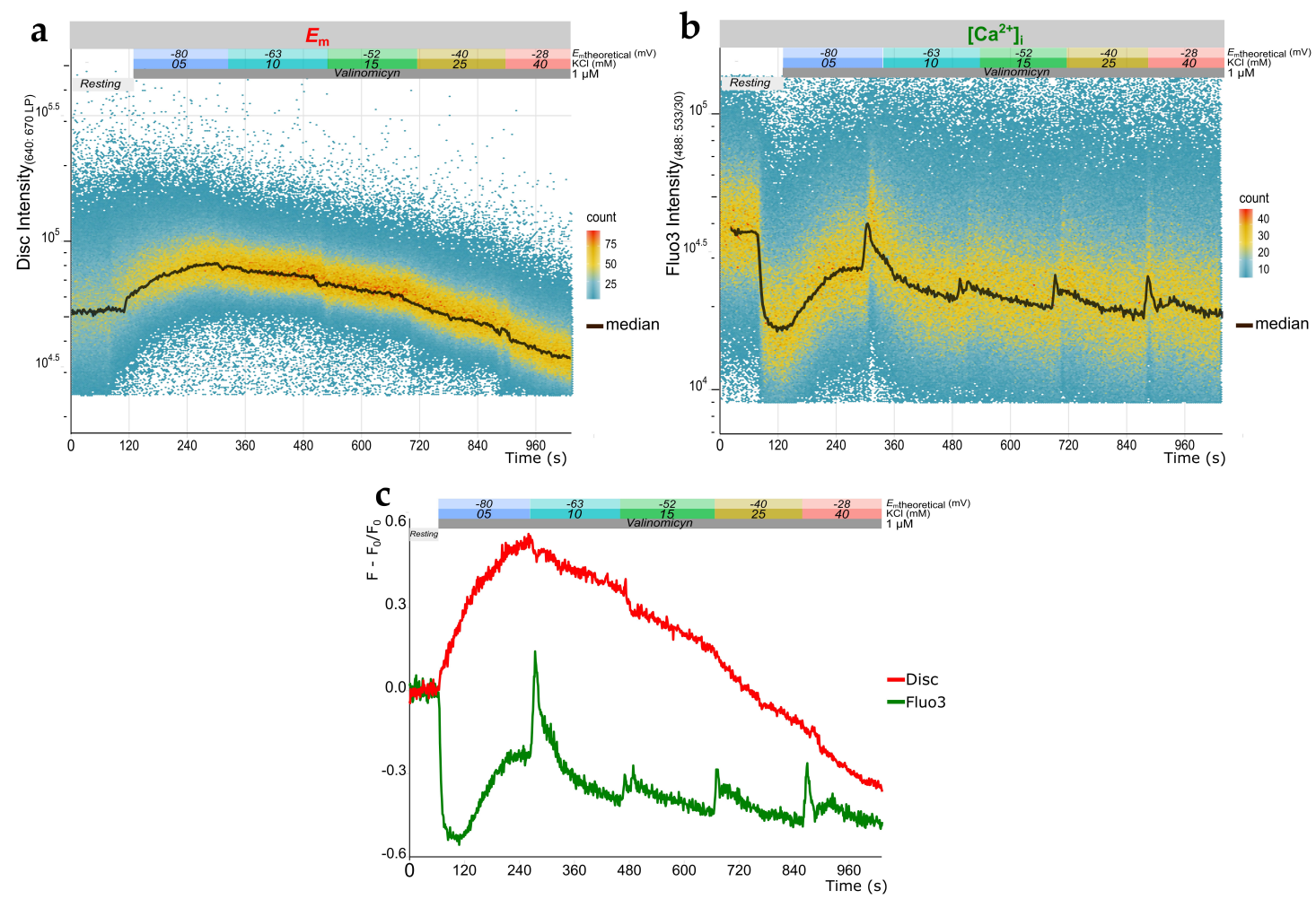

Figure 3. Multi-parametric measurement of membrane potential $\left(E_{\mathrm{m}}\right)$ and intracellular calcium concentration $\left(\left[\mathrm{Ca}{ }^{2+}\right]_{\mathrm{i}}\right)$ changes in human sperm. Representative time-lapse flow cytometry (TLFC) 4-(6-acetoxymethoxy-2,7-dichloro-3-oxo-9xanthenyl)-4'-methyl-2,2' (ethylenedioxy) dianiline- $\mathrm{N}, \mathrm{N}, \mathrm{N}^{\prime}, \mathrm{N}^{\prime}$-tetra acetic acid tetrakis (acetoxymethyl) ester (Fluo3-AM, abbreviated to Fluo3) fluorescence density plots of a sperm sample from a known paternity donor, which was co-stained with $\operatorname{DiSC}_{3}(5)$ (Disc) (a) and Fluo3 (b) to analyze $E_{\mathrm{m}}$ and $\left[\mathrm{Ca}^{2+}\right]_{\mathrm{i}}$ changes, respectively, under capacitating conditions. Colored boxes above the plots indicate the nature and duration of the employed stimuli. (c) Normalized median fluorescence values $\left(\left(\mathrm{F}-\mathrm{F}_{0}\right) / \mathrm{F}_{0}\right)$ of data shown in $(\mathbf{a})$ and $(\mathbf{b})$.

\subsection{Qualitative Analysis of $\left[\mathrm{Ca}^{2+}\right]_{i}$ Changes in Human Sperm Using TLFC Recordings}

The Pg-mediated opening of the sperm-specific cationic channel CatSper generates an $\left[\mathrm{Ca}^{2+}\right]_{i}$ increase $[21,22]$, which is involved in cellular processes essential for fertilization, such as motility changes and stimulation of the acrosomal reaction (AR) [38,39]. The CatSper channel is a multimeric protein complex composed of nine different subunits: CatSper1-4 are pore-forming subunits and the other five are distinct auxiliary subunits $(\beta, \gamma, \delta, \varepsilon$, and $\zeta)$ [40]. Interestingly, men harboring mutations or deletions on CatSper1- or 
CatSper2-encoding genes are infertile [41,42], and sperm samples from men undergoing ARTs present diminished responses to Pg compared to control samples from normozoospermic men $[25,29]$. For these reasons, we decided to test the suitability of TLFC for detecting the Pg-induced raise in $\left[\mathrm{Ca}^{2+}\right]_{\mathrm{i}}$.

Sperm samples were loaded with Fluo3 to follow $\left[\mathrm{Ca}^{2+}\right]_{i}$ variations. Basal Fluo3 fluorescence values were recorded during the first $120 \mathrm{~s}$. Immediately after this, $\operatorname{Pg}(4 \mu \mathrm{M})$ was added to the sperm suspension, triggering a fluctuation in $\left[\mathrm{Ca}^{2+}\right]_{i}$ as previously reported $[24,43,44]$. To obtain the maximum and minimum fluorescence values, we added the $\mathrm{Ca}^{2+}$ ionophore ionomycin $(10 \mu \mathrm{M})$ and manganese chloride $\left(\mathrm{Mn}^{2+}, 5 \mathrm{mM}\right)$, respectively, at the end of each recording (Figure 4a). As in the case of $E_{\mathrm{m}}$ measurements, we also evaluated the effect of Pg in sperm cells incubated under NC and CAP conditions. Figure $4 \mathrm{~b}$ shows the normalized fluorescence values for comparison purposes. For each of the sperm samples from known $(n=7)$ and no-known $(n=11)$ paternity donors, we compared the normalized fluorescence peaks $\left(\mathrm{F}_{\text {Peak }}\right)$ reached after Pg addition under NC and CAP conditions (Figure 4c). In samples from known paternity donors, we observed a greater and statistically significant response to Pg under CAP conditions compared to NC conditions $\left(\mathrm{F}_{\text {PeakNC }}=0.88 \pm 0.12\right.$ vs. $\left.\mathrm{F}_{\text {PeakCAP }}=1.90 \pm 0.27, p=0.0179\right)$. In contrast, we observed a wide range of responses among the samples from no-known paternity donors, and no statistically significant difference between $\mathrm{NC}$ and $\mathrm{CAP}$ conditions $\left(\mathrm{F}_{\text {PeakNC }}=1.64 \pm 0.34\right.$ vs. $\mathrm{F}_{\text {PeakCAP }}=1.96 \pm 0.36, p=0.3646$ ). To analyze the magnitude of the difference in $\mathrm{F}_{\text {Peak }}$ between $N C$ and CAP conditions, we calculated $\Delta \mathrm{F}_{\text {Peak }}=\mathrm{F}_{\text {PeakCAP }}-\mathrm{F}_{\text {PeakNC }}$ for each sample (Figure $4 \mathrm{~d}$ ). Considering that the standard error of the NC mean value for all 18 sperm samples was \pm 0.23 (data not shown), we arbitrarily established $\Delta \mathrm{F}_{\text {Peak }}= \pm 0.25$ as a threshold value to classify each individual sample as having either an increased, a decreased, or an unchanged Pg-induced change in $\left[\mathrm{Ca}^{2+}\right]_{i}$ upon capacitation. This revealed that $86 \%$ of samples from known paternity donors exhibited an increased Pg response under capacitation conditions, and only one out of seven (14\%) displayed no change. In contrast, $45 \%$ of samples from no-known paternity donors presented an increased response to $\mathrm{Pg}, 36 \%$ had no change, and 19\% showed a decreased Pg response upon capacitation (Figure 4e).

a

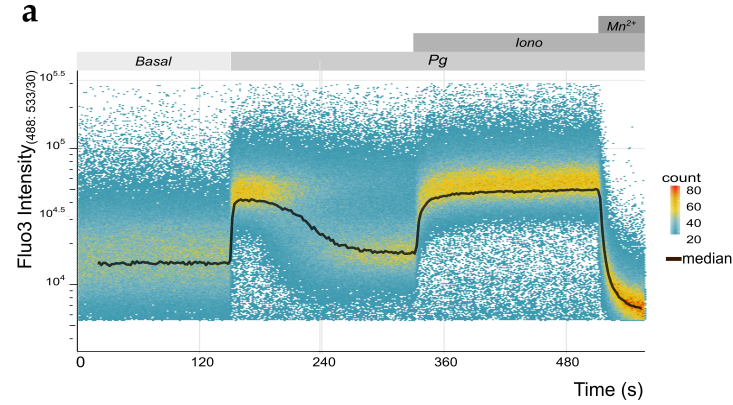

c

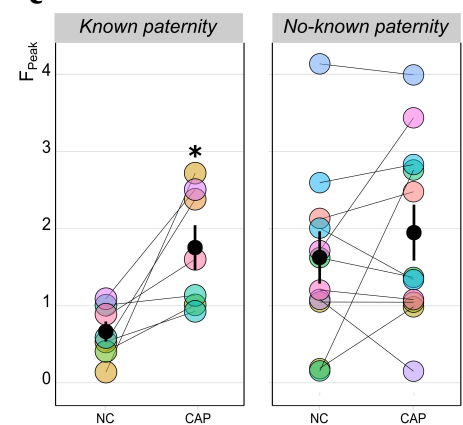

b

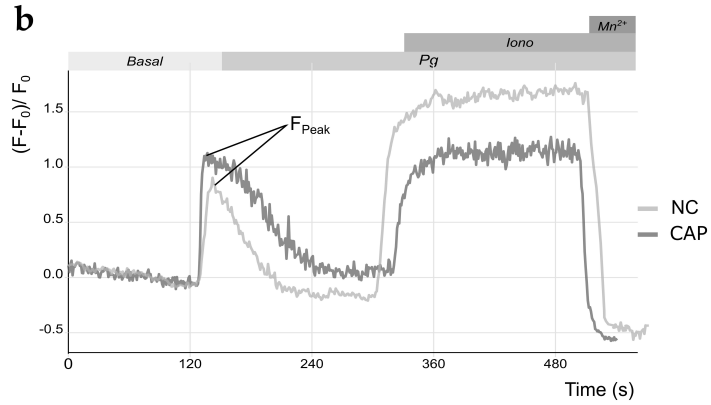

e

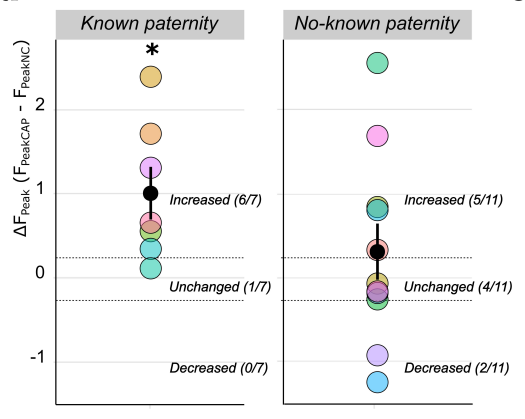

Known paternity No-known paternity

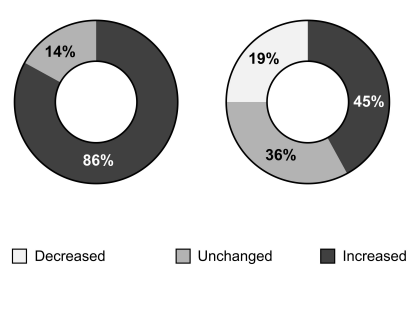

Figure 4. Qualitative evaluation of progesterone (Pg)-induced intracellular calcium concentration $\left[\mathrm{Ca}^{2+}\right]_{\mathrm{i}}$ changes in human sperm. (a) Representative time-lapse flow cytometry (TLFC) Fluo3-AM (Fluo3) fluorescence density plot of a sperm sample from a known paternity donor under capacitation conditions. Gray boxes above the plot indicate the nature and duration 
of the employed stimuli: progesterone (Pg), ionomycin (Iono), and manganese chloride $\left(\mathrm{Mn}^{2+}\right)$. The dark solid line indicates the median fluorescence value. (b) Representative example of normalized median fluorescence values $\left(\left(\mathrm{F}-\mathrm{F}_{0}\right) / \mathrm{F}_{0}\right)$ for an entire sperm population incubated under non-capacitating (NC) or capacitating (CAP) conditions. The $\mathrm{F}_{\text {Peak }}$ is indicated for both traces. Gray boxes above the plot indicate the nature and duration of the employed stimuli. (c) Comparison of $F_{\text {Peak }}$ responses for individual sperm samples (shown color-coded) from known $(n=7)$ and no-known $(n=11)$ paternity donors, incubated either under NC or CAP conditions. Black dots and solid lines indicate mean $\pm \mathrm{SEM}$; ${ }^{*} p<0.05$ according to a paired $t$-test. (d) Plots of the difference in $\mathrm{F}_{\text {Peak }}$ between NC and CAP conditions $\left(\Delta \mathrm{F}_{\text {Peak }}=\mathrm{F}_{\text {PeakCAP }}-\mathrm{F}_{\text {PeakNC }}\right)$ for samples in (c). Samples with a $\Delta \mathrm{F}_{\text {Peak }}$ greater, lower, or equal to \pm 0.25 were classified (dotted lines) as increased, decreased, or unchanged response, respectively; numbers in parentheses indicate the number of samples in each category out of the total. Black dots and solid lines indicate mean $\pm \mathrm{SEM} ;{ }^{*} p<0.05$ according to a one-sample $t$-test comparison against a theoretical mean of $\Delta \mathrm{F}_{\text {Peak }}=0$. (e) Donut charts depicting the distribution of the results shown in (d).

\subsection{Measurement of $p H_{i}$ Absolute Values in Human Sperm Using TLFC}

Intracellular alkalinization has been considered as a hallmark of the sperm capacitation process $[45,46]$. This physiological event is currently receiving attention from a clinical standpoint since a recent study reported that sperm samples from men undergoing ART did not display alkalinization [28]. In light of this, we decided to develop a protocol to determine absolute $\mathrm{pH}_{\mathrm{i}}$ values in human sperm cells using TLFC. We employed the pH-sensitive dye 2', $7^{\prime}$-bis-(2-carboxyethyl)-5-(and-6)-carboxyfluorescein acetoxymethyl ester (BCECF-AM, abbreviated to BCECF), which exhibits increased fluorescence when the cytoplasm becomes alkalinized, and decreased fluorescence upon acidification.

The chemical nature of BCECF makes it suitable as a viability marker as well, similar to Fluo3 (see Section 4.5 and Figure S1). Sperm samples from known $(n=8)$ and no-known $(n=6)$ paternity donors were initially incubated in human tubal fluid (HTF) medium under either $\mathrm{NC}$ or CAP conditions, and each one was divided into two aliquots. The first aliquot was used to record BCECF basal fluorescence for $120 \mathrm{~s}$, after which $\mathrm{NH}_{4} \mathrm{Cl}(20 \mathrm{mM})$ was added to artificially produce intracellular alkalinization (Figure $5 \mathrm{a}$ ). To obtain absolute $\mathrm{pH}_{\mathrm{i}}$ values, we placed the second aliquot in a calibration medium called $\mathrm{H}^{+} \mathrm{Cal}(\mathrm{pH} 6.0)$, which contains the $\mathrm{K}^{+} / \mathrm{H}^{+}$ionophore nigericin $(10 \mu \mathrm{M})$ and a relatively high concentration of $\mathrm{K}^{+}(120 \mathrm{mM})$. Incubation of sperm cells in $\mathrm{H}^{+}$Cal causes the collapse of the $\mathrm{H}^{+}$gradient across their $\mathrm{PM}$, equalizing the $\mathrm{pH}_{\mathrm{i}}$ with the extracellular $\mathrm{pH}\left(\mathrm{pH}_{\mathrm{e}}\right)$ of the medium [47]. We then started recording $\mathrm{BCECF}$ fluorescence; after $120 \mathrm{~s}$, we began sequential additions of $\mathrm{KOH}$ to elicit stepwise $\mathrm{pH}_{\mathrm{e}}$ increases, which resulted in equivalent increases in $\mathrm{pH}_{\mathrm{i}}$. These $\mathrm{KOH}$ additions were continued until a $\mathrm{pH}_{\mathrm{e}}\left(\right.$ and $\mathrm{pH}_{\mathrm{i}}$ ) of 8.0 was reached (Figure $5 \mathrm{~b}$ ). To convert fluorescence data into absolute $\mathrm{pH}_{\mathrm{i}}$ values, we followed the same protocol applied to $E_{\mathrm{m}}$ measurements (Section 2.1, Figure 2). Subpopulations of KOH-responding cells were selected (Figure $5 b$ ), and the median values obtained when BCECF fluorescence reached a plateau after each $\mathrm{KOH}$ addition were plotted against $\mathrm{pH}_{\mathrm{e}}$ (Figure $5 \mathrm{c}$ ). A linear model was adjusted to these data and used to obtain $\mathrm{pH}_{\mathrm{i}}$ values by interpolation. Figure $5 \mathrm{~d}$ shows the calculated $\mathrm{pH}_{\mathrm{i}}$ inside the histograms comparing BCECF fluorescence values from each cell subpopulation indicated in Figure 5a,b. In the representative example shown, the $\mathrm{pH}_{\mathrm{i}}$ of cells incubated under CAP conditions and after the $\mathrm{NH}_{4} \mathrm{Cl}$ stimulus were 6.76 and 7.32, respectively. 

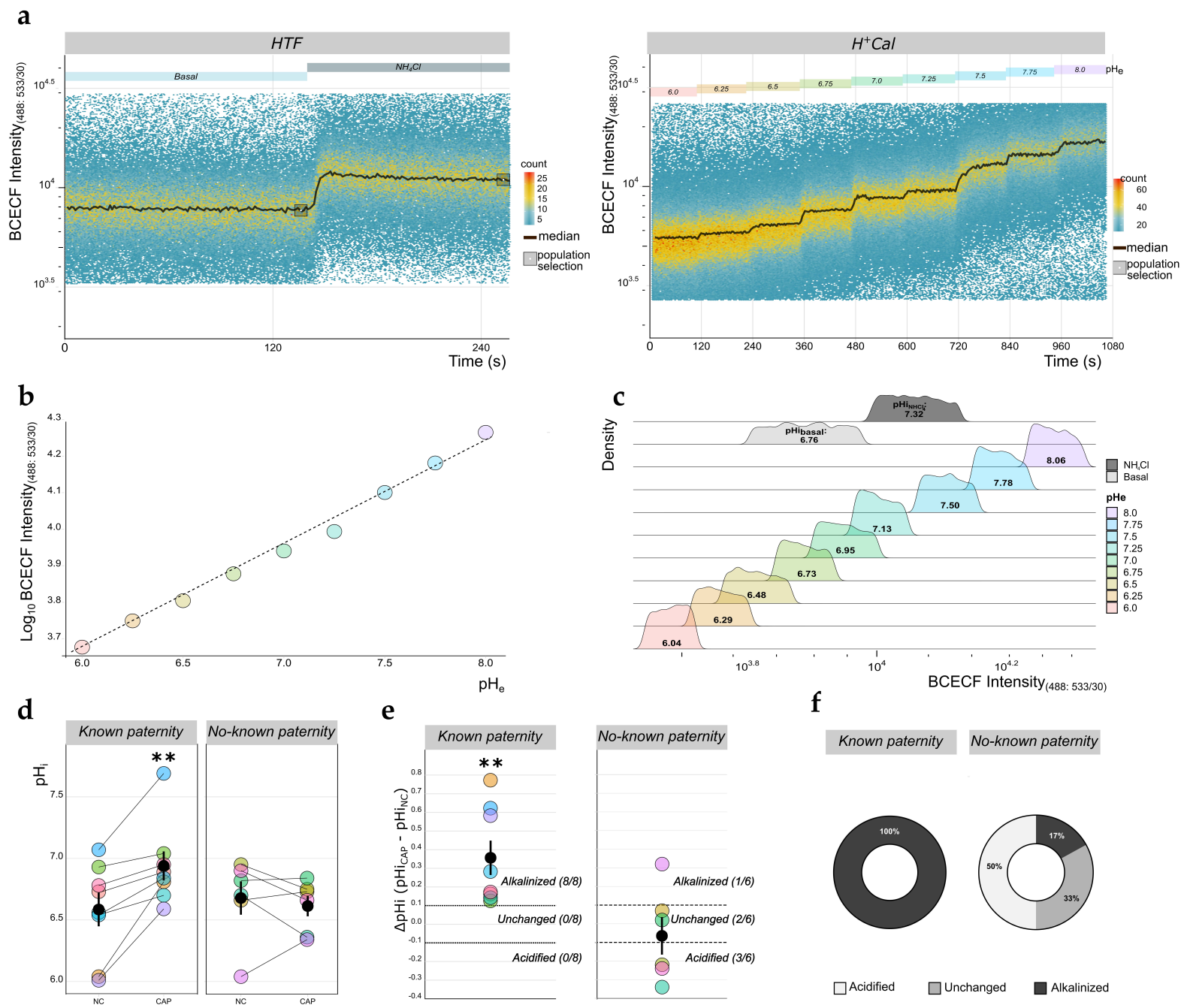

f

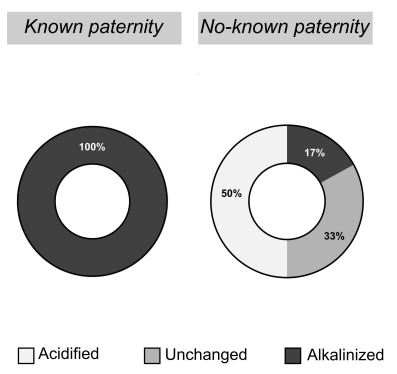

Figure 5. Measurement of intracellular $\mathrm{pH}\left(\mathrm{pH}_{\mathrm{i}}\right)$ absolute values in human sperm. (a) Representative time-lapse flow cytometry (TLFC) 2', $7^{\prime}$-bis-(2-carboxyethyl)-5-(and-6)-carboxyfluorescein acetoxymethyl ester (BCECF-AM, abbreviated to $\mathrm{BCECF}$ ) fluorescence density plots of a sperm sample from a known paternity donor incubated under non-capacitating (NC) conditions in either human tubal fluid (HTF) (left panel) or calibration $\left(\mathrm{H}^{+} \mathrm{Cal}\right)$ (right panel) medium. Colored boxes above the plots indicate the nature and duration of the employed stimuli. The dark solid lines indicate the median fluorescence values. Gray boxes enclose the cell subpopulations selected to perform further calculations. (b) Median $\log _{10}$-transformed BCECF fluorescence values of the selected subpopulations indicated in (a) (right panel) plotted against $\mathrm{pH}_{\mathrm{e}}$. The dashed line indicates the linear fit model $\left(y=-0.29 \mathrm{x}-1.93 ; R^{2}=0.99 ; p=7.5 \times 10^{-9}\right)$. (c). Density histograms of BCECF fluorescence values from the selected cell subpopulations indicated in (a) (right panel). For comparison, each colored histogram corresponds to each of the estimated $\mathrm{pH}_{\mathrm{i}}$ values (using the Henderson-Hasselbalch equation); the interpolated basal (light gray) and $\mathrm{NH}_{4} \mathrm{Cl}$-alkalinized (dark gray) $\mathrm{pH}$ values (indicated inside histograms) were 6.76 and 7.32, respectively. (d) Plots of estimated $\mathrm{pH}_{\mathrm{i}}$ values for individual sperm samples (shown color-coded) incubated under either NC or capacitating (CAP) conditions, from either known $(n=8)$ or no-known $(n=6)$ paternity donors. Black dots and solid lines indicate mean \pm SEM, respectively; ${ }^{* *} p<0.01$ against NC conditions according to a Wilcoxon matched-pairs signed-rank test. (e) Plots of the capacitation-induced $\mathrm{pH}_{\mathrm{i}}$ change $\left(\Delta \mathrm{pH}_{\mathrm{i}}=\mathrm{pH}_{\mathrm{iCAP}}-\mathrm{pH}_{\mathrm{iNC}}\right)$ for samples in (d). Samples with a $\Delta \mathrm{pH}_{\mathrm{i}}$ greater, lower, or equal to $\pm 0.1 \mathrm{pH}_{\mathrm{i}}$ units were classified (dotted lines) as alkalinized, acidified, or unchanged, respectively; numbers in parentheses indicate the number of samples in each category out of the total. Black dots and solid lines indicate mean \pm SEM, respectively; ${ }^{* *} p<0.01$ according to a one-sample $t$-test comparison against a theoretical mean of $\Delta \mathrm{pH}_{\mathrm{i}}=0$. (f) Donut charts depicting the distribution of the results shown in (e). 
Following the same protocol detailed for $E_{\mathrm{m}}$ measurements, we evaluated the changes in $\mathrm{pH}_{\mathrm{i}}$ upon capacitation in sperm samples from known $(n=8)$ and no-known $(n=6)$ paternity donors (Figure 5d). As expected, cytosolic alkalinization was observed in samples from known paternity donors upon capacitation, with an average difference of $0.36 \mathrm{pH}$ units $(6.58 \pm 0.14$ for NC versus $6.94 \pm 0.12$ for CAP conditions, $p=0.0078)$. Interestingly, we did not detect such a response when the average $\mathrm{pH}$ values for the no-known paternity samples were compared $(6.67 \pm 0.14$ for NC versus $6.61 \pm 0.08$ for CAP conditions, $p=$ 0.5469). To further analyze these data, we calculated the capacitation-induced $\mathrm{pH}_{\mathrm{i}}$ increase $\left(\Delta \mathrm{pH}_{\mathrm{i}}=\mathrm{pH}_{\mathrm{iCAP}}-\mathrm{pH}_{\mathrm{iNC}}\right)$ for each individual sample (Figure 5e). Similar to previous studies that have reported a $\mathrm{pH}_{\mathrm{i}}$ increase upon sperm capacitation [19-21], we established a $\Delta \mathrm{pH}_{\mathrm{i}}= \pm 0.1 \mathrm{pH}$ units as the threshold value to consider a sample as being alkalinized or acidified. On the basis of these criteria, we found that $100 \%(8 / 8)$ of the samples from known paternity donors exhibited the expected capacitation-associated $\mathrm{pH}_{\mathrm{i}}$ alkalinization. In contrast, only one out of six (17\%) of the samples from no-known paternity donors underwent $\mathrm{pH}_{\mathrm{i}}$ alkalinization upon capacitation, while 33\% of them remained unchanged and $50 \%$ became acidified (Figure 5f).

\section{Discussion}

The routine protocol used to assess sperm dysfunctions, the seminogram, does not encompass an evaluation of any of the capacitation-associated parameters required for fertilization (such as $E_{\mathrm{m}}, \mathrm{pH}_{\mathrm{i}}$, and $\left[\mathrm{Ca}^{2+}\right]_{\mathrm{i}}$ ), even though their suitability as potential predictors of success during the implementation of ARTs has been recognized [25-29]. The experimental methods employed to assess these parameters include single-cell and population-based protocols, which present some disadvantages, including the inability to detect heterogeneous responses, technical challenges, and/or restrictions in the number of analyzed cells. To overcome such limitations, we propose the use of a retrofitted BD Accuri C6 Plus flow cytometer as a tool to evaluate physiological parameters related to human sperm capacitation. Our strategy has several advantages over existing methods: it is less time consuming; it allows the exclusion of non-viable cells; it evaluates a number of cells which far exceeds that of single-cell techniques; it records heterogeneous responses; and most importantly, it enables time-lapse fluorescence recordings, which makes possible the continuous detection of responses upon addition of different chemical stimuli. This is in sharp contrast with stopped-flow cytometry methods where data acquisition must be interrupted for test compound additions, leading to information losses, especially in the case of fast and transient responses [25].

Vines and colleagues first employed the BD Accuri C6 Plus to perform kinetic fluorescence recordings of rapid $\left[\mathrm{Ca}^{2+}\right]_{i}$ changes in glioma cells [33]. Recently, Franchi and colleges applied for the first time this same approach to evaluate $\left[\mathrm{Ca}^{2+}\right]_{i}$ changes in bovine sperm cells [34]. Here, we improved the implementation of the method (TLFC) by custombuilding special glass tubes with a side opening to facilitate the continuous addition of test compounds. We also designed a 3D-printed special holder that enables placement of the sample tube on a magnetic stirrer to ensure a continuous homogenization of the cell suspension throughout the entire recording period.

The analysis of sperm $E_{\mathrm{m}}$ has gained clinical importance given that a high correlation between the sperm's fertilizing potential and its ability to undergo capacitation-related PM hyperpolarization has been reported [17,25-27]. Here, after successful calibration of fluorescence data from Disc, we were able to obtain absolute $E_{\mathrm{m}}$ values for the first time using TLFC. We observed a wide range of variability in resting $E_{\mathrm{m}}$ values across samples, consistent with previously reported values for human sperm [25-27]. Furthermore, in this work we analyzed the capacitation-induced changes in resting $E_{\mathrm{m}}$ in cell samples from normozoospermic donors of known and no-known paternity. We observed that $100 \%$ of the samples from known paternity donors displayed the expected capacitation-associated $E_{\mathrm{m}}$ hyperpolarization, in contrast with only $44 \%$ of samples from no-known paternity donors. Despite this, when the average magnitude of the capacitation-induced change in resting 
$\mathrm{E}_{m}$ was considered ( $-10 \mathrm{mV}$ for samples from known paternity donors), our result was only slightly different from the $-5 \mathrm{mV}$ change that was reported when measured through patchclamping (which is one of the most accurate methods to determine single-cell $E_{\mathrm{m}}$ ) [25]. It is worth mentioning that the average absolute resting $E_{\mathrm{m}}$ values thus far reported for human sperm under NC and CAP conditions varied considerably. For example, reported $E_{\mathrm{m}}$ resting values for $\mathrm{NC}$ and CAP conditions, respectively, were -10 to $-40 \mathrm{mV}$ (patch clamp [25]), -20 to $-80 \mathrm{mV}$ (stopped flow cytometry [27]), -44 to $-74 \mathrm{mV}$ [48], and -32 to $-54.6 \mathrm{mV}$ (spectrofluorometry [26]). The average $E_{\mathrm{m}}$ resting values obtained here by TLFC (considering samples from both known and no-known paternity donors) were $-63 \mathrm{mV}$ (NC) and $-71 \mathrm{mV}(\mathrm{CAP})$ (data not shown), which fell within the range of those measured through population-based approaches. Additionally, the difference we observed in resting $E_{\mathrm{m}}$ values between $\mathrm{NC}$ and CAP conditions $(-11 \mathrm{mV})$ was similar to that reported from those methods ( $-9 \mathrm{mV}$ for stopped-flow cytometry, and $-10 \mathrm{mV}$ for spectrofluorometry) [26,27]. Altogether, the data presented here support the use of TLFC as a robust tool to evaluate this very important parameter.

Considering that $\left[\mathrm{Ca}^{2+}\right]_{i}$ signaling is fundamental for sperm capacitation, we evaluated the Pg-evoked $\mathrm{Ca}^{2+}$ influx using TLFC. In all samples, we were able to observe the expected increase in $\left[\mathrm{Ca}^{2+}\right]_{i}$ upon $\mathrm{Pg}$ stimulation, consisting of a fast and transient $\left[\mathrm{Ca}^{2+}\right]_{i}$ increase followed by a sustained plateau $[24,43,44]$. Stopped-flow cytometry has been used to evaluate this response with no success, since the fast $\left[\mathrm{Ca}^{2+}\right]_{\mathrm{i}}$ increase is lost due to recording interruption [49]. Both fluorescence microscopy and spectrofluorometry are the most common methods currently employed to evaluate $\left[\mathrm{Ca}^{2+}\right]_{i}$ changes in sperm; as mentioned earlier, some of the disadvantages they present (a limitation in the number of cells that can be analyzed, and the impossibility of removing dead cells from the analysis, respectively) can be overcome by the use of TLFC. In this work, we decided to compare the $\left[\mathrm{Ca}^{2+}\right]_{i}$ response upon Pg stimulation in sperm cells incubated either under NC or CAP conditions, since previous studies have shown that the $\left[\mathrm{Ca}^{2+}\right]_{i}$ response increases by at least onefold upon capacitation [50-54]. As indicated before, all sperm samples displayed the typical $\mathrm{Pg}$ response; however, we observed high variability when comparing the magnitude of the $\left[\mathrm{Ca}^{2+}\right]_{i}$ increase in NC versus CAP conditions. An increased response to Pg under CAP conditions was only observed for $61 \%$ of all samples analyzed (6 out of 7 from known paternity donors, and 5 out of 11 from no-known paternity donors). Previous reports suggest that the differences in responses after a Pg stimulus depend on the basal $\left[\mathrm{Ca}^{2+}\right]_{i}$ of the sperm cells $[29,55]$, which we did not analyze. Positive outcomes during ART procedures have been associated with a high increase in $\left[\mathrm{Ca}^{2+}\right]_{i}$ after a Pg stimulus $[29,30,56]$, while small or null Pg responses have been found in patients with unsuccessful outcomes from ART treatments [27] and in oligozoospermic individuals [57]. Moreover, the sperm's eggpenetrating capability is also related to a high Pg response [55]. All these shreds of evidence indicate that the Pg-induced $\left[\mathrm{Ca}^{2+}\right]_{i}$ responses are relevant to provide predictive values of fertility outcomes. Our results indicate that TLFC is completely suitable to analyze these responses, providing key advantages over other commonly employed techniques.

Another benefit of TLFC is the possibility of combining different dyes for the simultaneous evaluation of more than one physiological parameter. We co-stained sperm cells with Fluo3 and Disc in order to monitor $\left[\mathrm{Ca}^{2+}\right]_{i}$ changes upon $E_{m}$ manipulation. After valinomycin-evoked $E_{m}$ hyperpolarization, a transient decrease in $\left[\mathrm{Ca}^{2+}\right]_{\mathrm{i}}$ was observed in most cases, and this was followed by a recovery phase that remained either below or similar to resting conditions. Then, a KCl-induced depolarization evoked a Ca ${ }^{2+}$ influx. These results are consistent with previous reports of voltage-dependent changes in $\left[\mathrm{Ca}^{2+}\right]_{\mathrm{i}}[52,58,59]$ that are presumably controlled by the CatSper channel, which presents a weak voltage dependency $[23,24,60]$. As mentioned before, this co-staining advantage of TLFC opens up the possibility of combining additional fluorescent dyes to further explore other physiological parameters in sperm. For instance, the simultaneous assessment of $\left[\mathrm{Ca}^{2+}\right]_{i}$ changes and the sperm's Pg-induced acrosome exocytosis could be performed using the appropriate combination of fluorescent labels (e.g., Fluo3 and a fluorescent- 
labeled lectin, respectively) [61]. This evaluation is of special interest, since the level of Pg-triggered acrosome exocytosis is yet another parameter associated with capacitation and fertility [30,62].

The rise in $\mathrm{pH}_{\mathrm{i}}$ has been recognized as a hallmark of mammalian sperm capacitation [19-21]. Mice and human sperm cells possess proteins whose dysfunction produces alterations in $\mathrm{pH}_{\mathrm{i}}$, and to some extent, impairs capacitation and reduces reproductive outcomes (reviewed in [45,46]). Here, we report the employment of TLFC as a robust tool to measure absolute $\mathrm{pH}_{\mathrm{i}}$ values in human sperm cells. The range of the calculated resting $\mathrm{pH}_{\mathrm{i}}$ values for the human sperm samples observed here (6.4 to 7.0) was within the reported range of $\mathrm{pH}_{\mathrm{i}}$ values that have been obtained using different methods, including spectrofluorometry (6.9 to 7.1) [20], fluorescence microscopy (6.7) [47], and even stopped-flow cytometry (6.7 to 7.0$)[28,63]$. Recently, the capacitation-associated alkalinization has been investigated from a clinical standpoint, with results suggesting that sperm samples from patients with fertility issues present an impaired regulation of $\mathrm{pH}_{\mathrm{i}}$ and fail to undergo the capacitation-associated alkalinization [28]. We thus explored the capacitation-associated alkalinization, which occurred consistently in all sperm samples from known paternity donors, but only in $17 \%$ of those from no-known paternity donors. A previous study reported that the average increase in $\mathrm{pH}_{\mathrm{i}}$ after $24 \mathrm{~h}$ of capacitation was around 0.2 units for normozoospermic samples [20]. The average $\mathrm{pH}$ change we obtained for samples from known paternity donors was 0.4 units. Such difference in the capacitation-associated $\Delta \mathrm{pH}_{\mathrm{i}}$ could be explained partly by the difference in capacitation time ( $24 \mathrm{~h}$ vs. $6 \mathrm{~h}$ in our experiments), and by the natural variability that exists among individuals. More research is required to obtain further information about the fertilization potential of samples that do not display the capacitation-induced $\mathrm{pH}_{\mathrm{i}}$ change. In summary, $\mathrm{pH}_{\mathrm{i}}$ is another capacitation-related parameter with clinical relevance that can be readily analyzed by TLFC.

The results provided in this work support the notion that $E_{\mathrm{m}}$ hyperpolarization, $\left[\mathrm{Ca}^{2+}\right]_{\mathrm{i}}$ responses to Pg stimulation, and cytoplasmic alkalinization are physiological parameters that may convey information of the fertilizing potential of sperm samples. Further investigation is required to establish putative normal response ranges for these parameters, as well as to understand the clinical significance whenever a given sample fails to display a response within such ranges. Even though the BD Accuri C6 cytometer is not an instrument commonly found in fertility clinics at this time, we propose that it is a suitable and cost-effective tool to perform sperm TLFC recordings aimed at guiding ART selection. The instrument retrofitting required for this application is reversible and straightforward, involving the use of readily available and inexpensive materials. One of the disadvantages of using this equipment, however, is that the filter/illumination configuration is fixed and thus the dye choices are limited. Nevertheless, the evaluation of the three capacitationassociated parameters described here, and potentially additional ones, could be useful as additional pieces of evidence when assessing the fertilizing potential of a given sperm sample. Moreover, since our method evaluates several parameters related to molecular processes involved in sperm function, it offers the potential of providing new and valuable information about the specific mechanisms that may be altered in sperm samples from infertile men. As such, we believe that our methodology may open up the door to a novel and more specific way of diagnosing and treating male infertility.

\section{Materials and Methods}

\subsection{Reagents}

Chemicals were obtained from the indicated sources: $2^{\prime}, 7^{\prime}$-bis-(2-carboxyethyl)-5-(and6)-carboxyfluorescein acetoxymethyl ester (BCECF-AM), 3,3'dipropylthiadicarbocyanine iodide ( $\left.\mathrm{DiSC}_{3}(5)\right)$, and 4-(6-acetoxymethoxy-2,7-dichloro-3-oxo-9-xanthenyl)-4'-methyl$2,2^{\prime}$ (ethylenedioxy) dianiline- $\mathrm{N}, \mathrm{N}, \mathrm{N}^{\prime}, \mathrm{N}^{\prime}$-tetra acetic acid tetrakis (acetoxymethyl) ester (Fluo3-AM) from ThermoFisher Scientific; ionomycin from Alomone; and all others from Sigma-Aldrich. Fluorescent dye and test compound stock solutions were prepared in 
Dimethyl sulfoxide (DMSO), except for those of $\mathrm{KCl}, \mathrm{KOH}, \mathrm{NH}_{4} \mathrm{Cl}$, and $\mathrm{MnCl}_{2}$, which were prepared in distilled water.

\subsection{Human Sperm Samples and Ethical Approval}

Human sperm sample collection was approved by the Bioethics Committee of the Instituto de Biotecnología (UNAM, Cuernavaca, Morelos, México. Approval 368 from 1 January 2019 to 31 December 2021). Written informed consent was obtained from all sperm donors. Only those samples that fulfilled the WHO guidelines for normal semen parameters (i.e., normozoospermic) were used in this study (lower reference limit: semen volume $=1.5 \mathrm{~mL}$, sperm number $=39 \times 10^{6}$, normal morphology $=4 \%$, total motility $=40 \%$, $\mathrm{pH}=7.2$ ) [5]. Sperm samples were obtained from 2 types of normozoospermic donors: (i) known paternity, subjects with self-reported paternity, and (ii) no-known paternity, subjects without self-reported paternity and with no known fertility problems.

\subsection{Human Sperm Sample Preparation}

Human ejaculated sperm samples were collected by masturbation after 3 to 5 days of sexual abstinence. Semen samples were liquefied for $30 \mathrm{~min}$ at $37^{\circ} \mathrm{C}$ in an atmosphere of $5 \% \mathrm{CO}_{2}$; from this point onwards, all sample incubations were performed under these temperature and atmosphere conditions. Motile cells were recovered through the swim-up method (sperm cells are allowed to swim from the semen sample into a buffer aliquot layered above it; see [44] for details) either in non-capacitating (NC) 4-(2-hydroxyethyl)-1piperazineethanesulfonic acid (HEPES)-buffered HTF medium (in mM: $90 \mathrm{NaCl}, 4.68 \mathrm{KCl}$, 2.78 glucose, $1.8 \mathrm{CaCl}_{2}, 0.37 \mathrm{KH}_{2} \mathrm{PO}_{4}, 0.2 \mathrm{MgSO}_{4}, 0.33$ sodium pyruvate, 21.39 sodium lactate, and 23.8 HEPES) or in capacitation-inducing (CAP) conditions, which consisted of HTF medium supplemented with $25 \mathrm{mM} \mathrm{NaHCO}_{3}$ and $0.5 \%(w / v)$ bovine serum albumin (BSA). Both media were adjusted to $\mathrm{pH} 7.4$ with $\mathrm{NaOH}$. After swim-up, sperm samples were incubated under NC or CAP conditions for $6 \mathrm{~h}$. Cells under NC or CAP conditions were loaded with $2 \mu \mathrm{M}$ Fluo3 for $30 \mathrm{~min}$, or with $300 \mathrm{nM}$ BCECF for 15 min protected from light. Excess dye was removed by centrifugation at $300 \times g$ for $5 \mathrm{~min}$, and the pellet was resuspended in NC or CAP medium to obtain a sperm concentration of $3 \times 10^{6}$ cells $/ \mathrm{mL}$. Finally, sperm cells were stained with $25 \mathrm{nM}$ Disc for $10 \mathrm{~min}$ protected from light.

\subsection{Experimental Setup to Perform TLFC}

Vines et al. established the use of the BD Accuri C6 Plus flow cytometer (Figure 1a) to perform continuous monitoring of $\left[\mathrm{Ca}^{2+}\right]_{i}$ in cells in suspension after sequential additions of test compounds [29]. We improved this strategy by using a custom-built system that facilitated the continuous addition of test compounds while ensuring their homogeneous mixing with the cell suspension and preventing their precipitation (Figure 1b), as many of them are dissolved in DMSO. We employed a modified glass tube with a side opening to ease the process of test compound solution additions by manual pipetting (Figure 1(b2,3)). We also designed and 3D-printed a special holder for these tubes (Figure 1(b5)). The modified glass tube containing the sperm cell suspension was placed on a magnetic stir plate (Four E's Scientific, Guangzhou, China) for the continuous mixing (105 rpm) of the suspension during the entire data acquisition period (Figure 1(b4,6)). This entire setup is shown in Figure 1.

\subsection{Data Acquisition and Selection of Viable Single Sperm Cells in the BD Accuri C6 Plus Flow Cytometer}

We performed acquisitions of cellular events in a continuous mode to obtain timelapse measurements with a flow rate of $14 \mu \mathrm{L} / \mathrm{min}$. All acquisitions were performed at a room temperature of $20^{\circ} \mathrm{C}$. Fluorescence data were recorded as individual cellular events on a BD Accuri C6 Plus flow cytometer (Becton Dickinson, Franklin Lakes, NJ, USA). Forward scatter (FSC) and side-scatter (SSC) fluorescence data were collected for each sample. Threshold levels for FSC and SSC were established to exclude cellular debris (Figure S1a), and a two-dimensional density plot of FSC height (FSC-H) versus FSC area 
(FSC-A) was used to eliminate cell aggregates from the analysis (Figure S1b). Only single cells were included in further analyses. The cytometer acquisition settings were as follows: to detect BCECF and Fluo3, we employed the $488 \mathrm{~nm}$ laser as the excitation source; BCECF and Fluo3 emission signals were detected in the FL-1 channel set with a 533/30 filter; Disc fluorescence was excited with a $640 \mathrm{~nm}$ laser, and its emission was detected in the FL4-channel set with a 670 LP filter.

To select viable cells, we followed the strategy reported by Puga-Molina et al. [64]. Either Fluo3 or BCECF staining was employed as a viability marker, since these dyes are incorporated only by healthy cells, and are excluded from non-viable cells. This is illustrated for the case of Fluo3 in Figure S1c. Heat-killed cells exhibit higher Fluo3 fluorescence intensity than unstained cells, but lower than viable cells. Therefore, we were able to establish a fluorescence intensity threshold to select viable cells for further analyses.

\subsection{Measurement of Absolute $E_{m}$ Values in Human Sperm}

The fluorescence signal of sperm cells loaded with Fluo3 and Disc was recorded after Disc steady-state fluorescence was reached. The $E_{\mathrm{m}}$ fluorescence signal was calibrated by adding $1 \mu \mathrm{M}$ valinomycin to induce PM hyperpolarization. Then, sequential additions of $\mathrm{KCl}$ were applied every $120 \mathrm{~s}$ to obtain final extracellular $\mathrm{K}^{+}$concentrations of 5,10 , 15,25 , and $40 \mathrm{mM}$ [16], corresponding to theoretical $E_{\mathrm{m}}$ values of $-80,-63-52-40$, and $-28 \mathrm{mV}$, respectively. These theoretical $E_{\mathrm{m}}$ values were obtained using the Nernst equation, assuming an intracellular $\mathrm{K}^{+}$concentration of $120 \mathrm{mM}$. To obtain the fluorescence values used to calculate the $E_{\mathrm{m}}$ values, we calculated the median fluorescence value of the responding sperm subpopulation when a plateau in the response was reached. The final sperm $E_{\mathrm{m}}$ value was then obtained by linear interpolation of the theoretical $E_{\mathrm{m}}$ values versus the median fluorescence values of each trace (see Section 2.1).

\subsection{Evaluation of $\left[\mathrm{Ca}^{2+}\right]_{i}$ Changes in Human Sperm}

$\left[\mathrm{Ca}^{2+}\right]_{\mathrm{i}}$ was monitored through fluorescent measurements of the cell-permeable calcium indicator Fluo3. Upon cell entry, the acetoxymethyl ester group (AM) of the dye is hydrolyzed by cytosolic esterases, and free Fluo3 accumulates in the cytosol. The fluorescence intensity of Fluo3 exhibits an increase upon binding $\mathrm{Ca}^{2+}$. Loaded Fluo3 sperm cells under either NC or CAP conditions were registered for $600 \mathrm{~s}$ to evaluate $\left[\mathrm{Ca}^{2+}\right]_{\mathrm{i}}$ changes. At $120 \mathrm{~s}$ after fluorescence recording began, $4 \mu \mathrm{M}$ Pg was added. To obtain the maximum fluorescence intensity, we added $10 \mu \mathrm{M}$ ionomycin after recording for $300 \mathrm{~s}$, followed by addition of $5 \mathrm{mM} \mathrm{MnCl}_{2}$ at $540 \mathrm{~s}$ to quench Fluo3 fluorescence and thus obtain a minimum fluorescence value.

\subsection{Measurement of Absolute $\mathrm{pH}_{i}$ Values in Human Sperm}

To determine $\mathrm{pH}_{\mathrm{i}}$ values, we loaded sperm cells with BCECF, a pH-sensitive cellpermeable probe. Free BCECF accumulates in the cytosol in the same way that Fluo3. In the case of samples incubated in CAP medium, cells were resuspended in medium without BSA prior to dye loading. Once sperm cells (either in NC or CAP medium) were loaded with BCECF, the cell suspension was divided into 2 equal parts and the excess dye was removed by centrifugation for $5 \mathrm{~min}$ at $300 \times \mathrm{g}$. One half of the suspension was incubated at $37^{\circ} \mathrm{C}$ during at least $15 \mathrm{~min}$ in a calibration medium, herein named $\mathrm{H}^{+} \mathrm{Cal}$ (in mM: $120 \mathrm{KCl}, 25 \mathrm{HEPES}, 1 \mathrm{MgCl}_{2}$, and 0.01 nigericin, adjusted to $\mathrm{pH} 6.0$ with $\mathrm{KOH}$ ). $\mathrm{H}^{+}$Cal medium allows the equilibration of $\mathrm{pH}_{\mathrm{i}}$ with the $\mathrm{pH}_{\mathrm{e}}$ through the effect of nigericin (an ionophore that facilitates $\mathrm{K}^{+} / \mathrm{H}^{+}$exchange across the PM). The other half of the cells were resuspended in HTF medium under either NC or CAP conditions.

To measure $\mathrm{pH}_{\mathrm{i}}$, we performed in vivo $\mathrm{pH}_{\mathrm{i}}$ calibration. BCECF fluorescence of sperm cells incubated in the $\mathrm{H}^{+} \mathrm{Cal}(\mathrm{pH}$ 6.0) medium was recorded for $120 \mathrm{~s}$. Then, sequential additions of solutions with different $\mathrm{KOH}$ concentrations were performed every $120 \mathrm{~s}$ to raise the $\mathrm{pH}_{\mathrm{e}} 0.25$ units, until reaching a final $\mathrm{pH}_{\mathrm{e}}$ of 8.0. The amount of $\mathrm{KOH}$ needed to raise the $\mathrm{pH} 0.25$ units was calculated using the Henderson-Hasselbalch equation, 
considering a $\mathrm{pKa}=7.55$ for $\mathrm{HEPES}$ at $20^{\circ} \mathrm{C}$. The $\mathrm{pH}_{\mathrm{i}}$ value of the sperm cell was obtained by recording the BCECF fluorescence of the cells resuspended in HTF medium under either $\mathrm{NC}$ or CAP conditions, and the absolute $\mathrm{pH}_{\mathrm{i}}$ value for each sperm sample was calculated by fitting a logarithmic model of the median fluorescence values from the responding sperm subpopulation versus the $\mathrm{pH}_{\mathrm{e}}$ value reached with each $\mathrm{KOH}$ addition. $\mathrm{An} \mathrm{NH}_{4} \mathrm{Cl}$ was performed in each $\mathrm{pH}_{\mathrm{i}}$ determination as a control of the responsiveness of the cells.

\subsection{Statistical Analyses}

Flow cytometry experimental data from the BD Accuri C6 Plus software were exported in Flow Cytometry Standard (FCS) format and initially analyzed with FlowJo Software version 10.1 (BD). Then, fluorescence and time data were exported into a comma-separated values (CSV) format and analyzed in RStudio version 1.3.1093 [65]. Fluorescence data are shown as density plots where warm colors represent high cell density. Black lines in density plots represent smoothed traces of each recording, which corresponds to the median fluorescence value for each given time point (obtained in FlowJo with the Kinetics function). Graphs were created with ggplot2 and ggpubr [66]. The results obtained for $E_{\mathrm{m}}$ values, $\mathrm{Pg}$-triggered peak $\left[\mathrm{Ca}^{2+}\right]_{\mathrm{i}}$ fluorescence, and $\mathrm{pH}_{\mathrm{i}}$ values were first separated into the 2 donor classes-known paternity and no-known paternity. In each of these groups, paired comparisons were performed between NC and CAP conditions by a paired $t$ test or a Wilcoxson signed-rank test, depending on whether or not the data passed the Shapiro-Wilk normality test, respectively. After calculating the $\Delta E_{\mathrm{m}}\left(E_{\mathrm{mCAP}}-E_{\mathrm{mNC}}\right)$, $\Delta \mathrm{F}_{\text {Peak }}\left(\mathrm{F}_{\text {PeakCAP }}-\mathrm{F}_{\text {PeakNC }}\right)$, and $\Delta \mathrm{pH}_{\mathrm{i}}\left(\mathrm{pH}_{\mathrm{iCAP}}-\mathrm{pH}_{\mathrm{iNC}}\right)$, we performed a one-sample $t$-test comparison against theoretical mean $=0$ for each donor class-known paternity and no-known paternity (calculations were performed in GraphPad Prism 8). A probability value $(p)<0.05$ was considered as a statistically significant difference. The final versions of the figures were made in Inkscape 0.91 (Inkscape.org).

Supplementary Materials: Supplementary materials can be found at https://www.mdpi.com/1422 $-0067 / 22 / 1 / 93 / s 1$.

Author Contributions: Conceptualization, A.M.-V., V.C.-V. and C.L.T.; methodology, A.M.-V., V.C.-V., P.T.-R. and C.L.T.; software, A.M.-V. and V.C.-V.; validation, A.M.-V. and V.C.-V.; formal analysis, A.M.-V. and V.C.-V.; investigation, A.M.-V., P.T.-R. and V.C.-V.; resources, C.L.T.; data curation, A.M.-V., V.C.-V. and P.T.-R.; writing-original draft preparation, A.M.-V. and V.C.-V.; writing-review and editing, A.M.-V., V.C.-V., P.T.-R., M.B.T. and C.L.T.; visualization, A.M.-V., V.C.-V. and M.B.T.; supervision, C.L.T.; project administration, C.L.T.; funding acquisition, C.L.T. All authors have read and agreed to the published version of the manuscript.

Funding: This research was funded by Direccion General de Asuntos del Personal AcademicoUNAM-Mexico (IN202519 to C.L.T.). A.M.-V. and V.C.-V. are students of the Doctorado en Ciencias Bioquímicas-UNAM program supported by Consejo Nacional de Ciencia y Tecnología (CONACyT) scholarships.

Acknowledgments: We recognize the value of preliminary experiments performed by Diana Laura Lobato. We thank Yoloxóchilt Sánchez Guevara and José Luis De la Vega Beltrán for technical assistance. We are grateful to Emiliano Velazquez for designing and 3D printing the tube holder. We acknowledge Cecilia Juárez Treviño for the preparation of Figure 1, and Mariana Olivares Urbano for her support in the creation of all other figures. We thank Shirley Ainsworth for library support. We acknowledge Juan Manuel Hurtado Ramírez, Roberto Pablo Rodríguez Bahena, Omar Arriaga Pérez, Servando Aguirre Cruz, David Santiago Castañeda Carreón, and Arturo Ocádiz Ramírez for computer services. We give special thanks to the members of the Laboratorio de Análisis de Moléculas y Medicamentos Biotecnológicos (LAMMB, IBT, UNAM), in particular to Laura Alicia Palomares Aguilera and Roberta Salinas Marín, for the use of their facilities and the BD Accuri C6 Plus flow cytometer.

Conflicts of Interest: The authors declare no conflict of interest. The funders had no role in the design of the study; in the collection, analyses, or interpretation of data; in the writing of the manuscript, or in the decision to publish the results. 


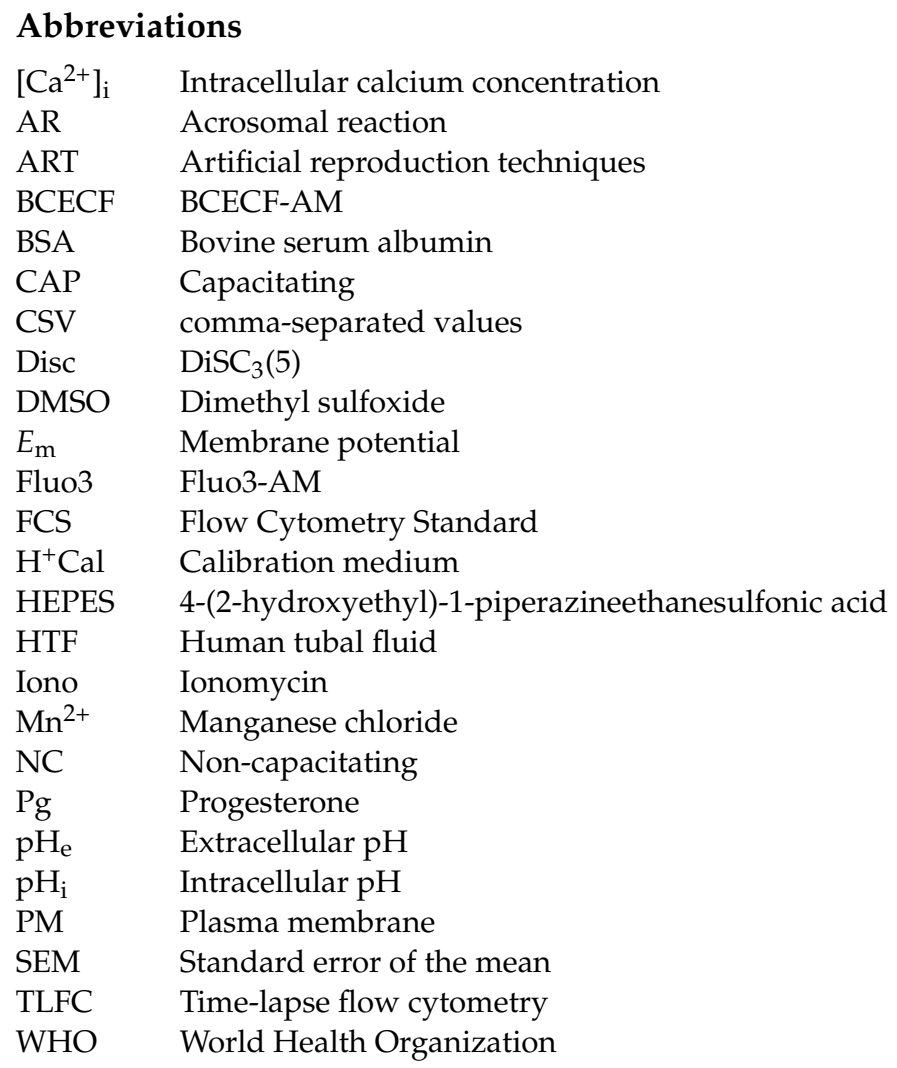

\section{References}

1. Sharma, R.; Biedenharn, K.R.; Fedor, J.M.; Agarwal, A. Lifestyle factors and reproductive health: Taking control of your fertility. Reprod. Biol. Endocrinol. 2013, 11, 1. [CrossRef] [PubMed]

2. HFEA. Fertility Treatment 2014. Trends and Figures. Available online: https://www.hfea.gov.uk/media/1111/hfea-fertilitytreatment-trends-and-figures-2014.pdf (accessed on 27 November 2020).

3. Kumar, N.; Singh, A. Trends of male factor infertility, an important cause of infertility: A review of literature. J. Hum. Reprod. Sci. 2015, 8, 191-196. [CrossRef] [PubMed]

4. Barratt, C.L.R.; Björndahl, L.; De Jonge, C.J.; Lamb, D.J.; Martini, F.O.; McLachlan, R.; Oates, R.D.; van der Poel, S.; John, B.S.; Sigman, M.; et al. The diagnosis of male infertility: An analysis of the evidence to support the development of global WHO guidance-challenges and future research opportunities. Hum. Reprod. Update 2017, 23, 660-680. [CrossRef] [PubMed]

5. Ford, W.C.L. Comments on the release of the 5th edition of the WHO Laboratory Manual for the Examination and Processing of Human Semen. Asian J. 2010, 12, 59-63. [CrossRef]

6. Cooper, T.G.; Noonan, E.; von Eckardstein, S.; Auger, J.; Baker, H.W.G.; Behre, H.M.; Haugen, T.B.; Kruger, T.; Wang, C.; Mbizvo, M.T.; et al. World Health Organization reference values for human semen characteristics. Hum. Reprod. Update 2010, 16, 231-245. [CrossRef]

7. Guzick, D.S.; Overstreet, J.W.; Factor-Litvak, P.; Brazil, C.K.; Nakajima, S.T.; Coutifaris, C.; Carson, S.A.; Cisneros, P.; Steinkampf, M.P.; Hill, J.A.; et al. Sperm Morphology, Motility, and Concentration in Fertile and Infertile Men. N. Engl. J. Med. 2001, 345, 1388-1393. [CrossRef]

8. MacLeod, J. The Male Factor in Fertility and Infertility: An Analysis of Ejaculate Volume in 800 Fertile Men and in 600 Men in Infertile Marriage. Fertil. Steril. 1950, 1, 347-361. [CrossRef]

9. Björndahl, L. What is normal semen quality? On the use and abuse of reference limits for the interpretation of semen analysis results. Hum. Fertil. 2011, 14, 179-186. [CrossRef]

10. Bracke, A.; Peeters, K.; Punjabi, U.; Hoogewijs, D.; Dewilde, S. A search for molecular mechanisms underlying male idiopathic infertility. Reprod. Biomed. Online 2018, 36, 327-339. [CrossRef]

11. Tosti, E.; Ménézo, Y. Gamete activation: Basic knowledge and clinical applications. Hum. Reprod. Update 2016, 22, 420-439. [CrossRef]

12. Chang, M. Fertilizing Capacity of Spermatozoa deposited into the Fallopian Tubes. Nature 1951, 168, 697-698. [CrossRef] [PubMed]

13. Austin, C.R. Observations on the penetration of the sperm in the mammalian egg. Aust. J. Biol. Sci. 1951, 4, 581-596. [CrossRef] [PubMed]

14. Puga Molina, L.C.; Luque, G.M.; Balestrini, P.A.; Marín-Briggiler, C.I.; Romarowski, A.; Buffone, M.G. Molecular Basis of Human Sperm Capacitation. Front. Cell Dev. Biol. 2018, 6, 1-23. [CrossRef] [PubMed] 
15. Lopez-Gonzalez, I.; Torres-Rodriguez, P.; Sanchez-Carranza, O.; Solis-Lopez, A.; Santi, C.M.; Darszon, A.; Trevino, C.L. Membrane hyperpolarization during human sperm capacitation. Mol. Hum. Reprod. 2014, 20, 619-629. [CrossRef] [PubMed]

16. Baro Graf, C.; Ritagliati, C.; Stival, C.; Balestrini, P.A.; Buffone, M.G.; Krapf, D. Determination of a robust assay for human sperm membrane potential analysis. Front. Cell Dev. Biol. 2019, 7, 1-9. [CrossRef]

17. Zeng, Y.; Clark, E.N.; Florman, H.M. Sperm membrane potential: Hyperpolarization during capacitation regulates zona pellucidadependent acrosomal secretion. Dev. Biol. 1995, 171, 554-563. [CrossRef]

18. Tosti, E.; Boni, R. Electrical events during gamete maturation and fertilization in animals and humans. Hum. Reprod. Update 2004, 10, 53-65. [CrossRef]

19. Matamoros-Volante, A.; Treviño, C.L. Capacitation-associated alkalization in human sperm is differentially controlled at the subcellular level. J. Cell Sci. 2020, 133. [CrossRef]

20. Cross, N.L.; Razy-Faulkner, P. Control of human sperm intracellular pH by cholesterol and its relationship to the response of the acrosome to progesterone. Biol. Reprod. 1997, 56, 1169-1174. [CrossRef]

21. Hamamah, S.; Magnoux, E.; Royere, D.; Barthelemy, C.; Dacheux, J.L.; Gatti, J.L. Internal pH of human spermatozoa: Effect of ions, human follicular fluid and progesterone. Mol. Hum. Reprod. 1996, 2, 219-224. [CrossRef]

22. Miller, M.R.; Mannowetz, N.; Iavarone, A.T.; Safavi, R.; Gracheva, E.O.; Smith, J.F.; Hill, R.Z.; Bautista, D.M.; Kirichok, Y.; Lishko, P. V Unconventional endocannabinoid signaling governs sperm activation via the sex hormone progesterone. Science 2016, 352, 555-559. [CrossRef] [PubMed]

23. Lishko, P.V.; Botchkina, I.L.; Kirichok, Y. Progesterone activates the principal Ca ${ }^{2+}$ channel of human sperm. Nature 2011, 471, 387-392. [CrossRef] [PubMed]

24. Strünker, T.; Goodwin, N.; Brenker, C.; Kashikar, N.D.; Weyand, I.; Seifert, R.; Kaupp, U.B. The CatSper channel mediates progesterone-induced $\mathrm{Ca}^{2+}$ influx in human sperm. Nature 2011, 471, 382-387. [CrossRef] [PubMed]

25. Brown, S.G.; Publicover, S.J.; Mansell, S.A.; Lishko, P.V.; Williams, H.L.; Ramalingam, M.; Wilson, S.M.; Barratt, C.L.R.; Sutton, K.A.; Da Silva, S.M. Depolarization of sperm membrane potential is a common feature of men with subfertility and is associated with low fertilization rate at IVF. Hum. Reprod. 2016, 31, 1147-1157. [CrossRef]

26. Baro Graf, C.; Ritagliati, C.; Torres-Monserrat, V.; Stival, C.; Carizza, C.; Buffone, M.G.; Krapf, D. Membrane Potential Assessment by Fluorimetry as a Predictor Tool of Human Sperm Fertilizing Capacity. Front. Cell Dev. Biol. 2020, 7, 1-10. [CrossRef]

27. Puga-Molina, L.C.P.; Gunderson, S.; Riley, J.; Lybaert, P.; Borrego-Alvarez, A.; Jungheim, E.S.; Santi, C.M. Membrane Potential Determined by Flow Cytometry Predicts Fertilizing Ability of Human Sperm. Front. Cell Dev. Biol. 2020, 7, 1-12. [CrossRef]

28. Gunderson, S.; Puga Molina, L.C.; Riley, J.; Jungheim, E.S.; Santi, C.M. Sperm intracellular pH as a predictor of fertilization rate in normospermic infertile men undergoing in vitro fertilization. Fertil. Steril. 2019, 112, e201-e202. [CrossRef]

29. Kelly, M.C.; Brown, S.G.; Costello, S.M.; Ramalingam, M.; Drew, E.; Publicover, S.J.; Barratt, C.L.R.; Da Silva, S.M. Single-cell analysis of $\left[\mathrm{Ca}^{2+}\right]_{i}$ signalling in sub-fertile men: Characteristics and relation to fertilization outcome. Hum. Reprod. 2018, 33, 1023-1033. [CrossRef]

30. Krausz, C.; Bonaccorsi, L.; Luconi, M.; Fuzzi, B.; Criscuoli, L.; Pellegrini, S.; Forti, G.; Baldi, E. Intracellular calcium increase and acrosome reaction in response to progesterone in human spermatozoa are correlated with in-vitro fertilization. Hum. Reprod. 1995, 10, 120-124. [CrossRef]

31. Darszon, A.; Nishigaki, T.; Wood, C.; Treviño, C.L.; Felix, R.; Beltrán, C. Calcium channels and Ca ${ }^{2+}$ fluctuations in sperm physiology. Int. Rev. Cytol. 2005, 243, 79-172. [CrossRef]

32. Kirichok, Y.; Lishko, P.V. Rediscovering sperm ion channels with the patch-clamp technique. Mol. Hum. Reprod. 2011, 17, 478-499. [CrossRef] [PubMed]

33. Vines, A.; McBean, G.J.; Blanco-Fernández, A. A flow-cytometric method for continuous measurement of intracellular Ca ${ }^{2+}$ concentration. Cytom. Part A 2010, 77A, 1091-1097. [CrossRef] [PubMed]

34. Franchi, A.; Moreno-Irusta, A.; Domínguez, E.M.; Adre, A.J.; Giojalas, L.C. Extracellular vesicles from oviductal isthmus and ampulla stimulate the induced acrosome reaction and signaling events associated with capacitation in bovine spermatozoa. J. Cell. Biochem. 2020, 121, 2877-2888. [CrossRef] [PubMed]

35. Navarro, B.; Kirichok, Y.; Clapham, D.E. KSper, a pH-sensitive K+ current that controls sperm membrane potential. Proc. Natl. Acad. Sci. USA 2007, 104, 7688-7692. [CrossRef]

36. Ritagliati, C.; Baro Graf, C.; Stival, C.; Krapf, D. Regulation mechanisms and implications of sperm membrane hyperpolarization. Mech. Dev. 2018, 154, 33-43. [CrossRef]

37. Plášek, J.; Hrouda, V. Assessment of membrane potential changes using the carbocyanine dye, diS-C3-(5): Synchronous excitation spectroscopy studies. Eur. Biophys. J. 1991, 19, 183-188. [CrossRef]

38. Darszon, A.; Nishigaki, T.; Beltran, C.; Trevino, C.L. Calcium Channels in the Development, Maturation, and Function of Spermatozoa. Physiol. Rev. 2011, 91, 1305-1355. [CrossRef]

39. Lishko, P.V.; Kirichok, Y.; Ren, D.; Navarro, B.; Chung, J.J.; Clapham, D.E. The control of male fertility by spermatozoan ion channels. Annu. Rev. Physiol. 2012, 74, 453-475. [CrossRef]

40. Darszon, A.; Nishigaki, T.; López-González, I.; Visconti, P.E.; Treviño, C.L. Differences and similarities: The richness of comparative sperm physiology. Physiology 2020, 35, 196-208. [CrossRef]

41. Avenarius, M.R.; Hildebrand, M.S.; Zhang, Y.; Meyer, N.C.; Smith, L.L.H.; Kahrizi, K.; Najmabadi, H.; Smith, R.J.H. Human Male Infertility Caused by Mutations in the CATSPER1 Channel Protein. Am. J. Hum. Genet. 2009, 84, 505-510. [CrossRef] 
42. Avidan, N.; Tamary, H.; Dgany, O.; Cattan, D.; Pariente, A.; Thulliez, M.; Borot, N.; Moati, L.; Barthelme, A.; Shalmon, L.; et al. CATSPER2, a human autosomal nonsyndromic male infertility gene. Eur. J. Hum. Genet. 2003, 11, 497-502. [CrossRef] [PubMed]

43. Kirkman-Brown, J.C.; Bray, C.; Stewart, P.M.; Barratt, C.L.R.; Publicover, S.J. Biphasic elevation of $\left[\mathrm{Ca}^{2+}\right](\mathrm{i})$ in individual human spermatozoa exposed to progesterone. Dev. Biol. 2000, 222, 326-335. [CrossRef] [PubMed]

44. Mata-Martínez, E.; José, O.; Torres-Rodríguez, P.; Solís-López, A.; Sánchez-Tusie, A.A.; Sánchez-Guevara, Y.; Treviño, M.B.; Treviño, C.L. Measuring intracellular $\mathrm{Ca}^{2+}$ changes in human sperm using four techniques: Conventional fluorometry, stopped flow fluorometry, flow cytometry and single cell imaging. J. Vis. Exp. 2013, e50344. [CrossRef]

45. Mishra, A.K.; Kumar, A.; Swain, D.K.; Yadav, S.; Nigam, R. Insights into pH regulatory mechanisms in mediating spermatozoa functions. Vet. World 2018, 11, 852-858. [CrossRef]

46. Nishigaki, T.; José, O.; González-Cota, A.L.; Romero, F.; Treviño, C.L.; Darszon, A. Intracellular pH in sperm physiology. Biochem. Biophys. Res. Commun. 2014, 450, 1149-1158. [CrossRef]

47. Chávez, J.C.; Darszon, A.; Treviño, C.L.; Nishigaki, T. Quantitative Intracellular pH Determinations in Single Live Mammalian Spermatozoa Using the Ratiometric Dye SNARF-5F. Front. Cell Dev. Biol. 2020, 7, 1-13. [CrossRef]

48. Patrat, C.; Serres, C.; Jouannet, P. Progesterone induces hyperpolarization after a transient depolarization phase in human spermatozoa. Biol. Reprod. 2002, 66, 1775-1780. [CrossRef]

49. Brewis, I.A.; Morton, I.E.; Mohammad, S.N.; Browes, C.E.; Moore, H.D.M. Measurement of intracellular calcium concentration and plasma membrane potential in human spermatozoa using flow cytometry. J. Androl. 2000, 21, 238-249. [CrossRef]

50. Baldi, E.; Casano, R.; Falsetti, C.; Krausz, C.; Maggi, M.; Forti, G. Intracellular Calcium Accumulation and Responsiveness to Progesterone in Capacitating Human Spermatozoa. J. Androl. 1991, 12, 323-330. [CrossRef]

51. Garcia, M.A.; Meizel, S. Progesterone-Mediated Calcium Influx and Acrosome Reaction of Human Spermatozoa: Pharmacological Investigation of T-Type Calcium Channels1. Biol. Reprod. 1999, 60, 102-109. [CrossRef]

52. González-Martínez, M.T.; Bonilla-Hernández, M.A.; Guzmán-Grenfell, A.M. Stimulation of voltage-dependent calcium channels during capacitation and by progesterone in human sperm. Arch. Biochem. Biophys. 2002, 408, 205-210. [CrossRef]

53. Mendoza, C.; Tesarik, J. A plasma-membrane progesterone receptor in human sperm is switched on by increasing intracellular free calcium. FEBS Lett. 1993, 330, 57-60. [CrossRef]

54. Torres-Flores, V.; Hernandez-Rueda, Y.L.; del Carmen Neri-Vidaurri, P.; Jimenez-Trejo, F.; Calderon-Salinas, V.; Molina-Guarneros, J.A.; Gonzalez-Martinez, M.T. Activation of Protein Kinase A Stimulates the Progesterone-Induced Calcium Influx in Human Sperm Exposed to the Phosphodiesterase Inhibitor Papaverine. J. Androl. 2008, 29, 549-557. [CrossRef] [PubMed]

55. Shimizu, Y.; Nord, E.P.; Bronson, R.A. Progesterone-evoked increases in sperm $\left[\mathrm{Ca}^{2+}\right]$ i correlate with the egg penetrating ability of sperm from fertile but not infertile men. Fertil. Steril. 1993, 60, 526-532. [CrossRef]

56. Krausz, C.; Bonaccorsi, L.; Maggio, P.; Luconi, M.; Criscuoli, L.; Fuzzi, B.; Pellegrini, S.; Forti, G.; Baldi, E. Two functional assays of sperm responsiveness to progesterone and their predictive values in in-vitro fertilization. Hum. Reprod. 1996, 11, $1661-1667$. [CrossRef] [PubMed]

57. Falsetti, C.; Baldi, E.; Krausz, C.; Casano, R.; Failli, P.; Forti, G. Decreased Responsiveness to Progesterone of Spermatozoa in Oligozoospermic Patients. J. Androl. 1993, 14, 17-22. [CrossRef]

58. Guzmán-Grenfell, A.M.; González-Martínez, M.T. Lack of Voltage-Dependent Calcium Channel Opening During the Calcium Influx Induced by Progesterone in Human Sperm. Effect of Calcium Channel Deactivation and Inactivation. J. Androl. 2004, 25, 117-122. [CrossRef]

59. Linares-Hernández, L.; Guzmán-Grenfell, A.M.; Hicks-Gomez, J.J.; González-Martínez, M.T. Voltage-dependent calcium influx in human sperm assessed by simultaneous optical detection of intracellular calcium and membrane potential. Biochim. Biophys. Acta (BBA)-Biomembr. 1998, 1372, 1-12. [CrossRef]

60. Kirichok, Y.; Navarro, B.; Clapham, D.E. Whole-cell patch-clamp measurements of spermatozoa reveal an alkaline-activated Ca ${ }^{2+}$ channel. Nature 2006, 439, 737-740. [CrossRef]

61. Balestrini, P.A.; Jabloñski, M.; Schiavi-Ehrenhaus, L.J.; Marín-Briggiler, C.I.; Sánchez-Cárdenas, C.; Darszon, A.; Krapf, D.; Buffone, M.G. Seeing is believing: Current methods to observe sperm acrosomal exocytosis in real time. Mol. Reprod. Dev. 2020. [CrossRef]

62. Chen, X.; Zheng, Y.; Zheng, J.; Lin, J.; Zhang, L.; Jin, J. The progesterone-induced sperm acrosome reaction is a good option for the prediction of fertilization in vitro compared with other sperm parameters. Andrologia 2019, 51. [CrossRef] [PubMed]

63. Lachance, C.; Goupil, S.; Tremblay, R.R.; Leclerc, P. The immobilization of human spermatozoa by STAT3 inhibitory compound V results from an excessive intracellular amount of reactive oxygen species. Andrology 2016, 4, 133-142. [CrossRef] [PubMed]

64. Puga Molina, L.C.; Pinto, N.A.; Torres Rodríguez, P.; Romarowski, A.; Vicens Sanchez, A.; Visconti, P.E.; Darszon, A.; Treviño, C.L.; Buffone, M.G. Essential Role of CFTR in PKA-Dependent Phosphorylation, Alkalinization, and Hyperpolarization During Human Sperm Capacitation. J. Cell. Physiol. 2017, 232, 1404-1414. [CrossRef] [PubMed]

65. RStudio Team. RStudio: Integrated Development Environment for R 2020; RStudio Team: Bostom, MA, USA, 2020.

66. Wickham, H. ggplot2: Elegant Graphics for Data Analysis; Springer: New York, NY, USA, 2009; ISBN 978-0-387-98140-6. 